\title{
Photosynthetic production in the central Arctic Ocean during the record sea-ice minimum in 2012
}

\author{
M. Fernández-Méndez ${ }^{1,2}$, C. Katlein ${ }^{1}$, B. Rabe ${ }^{1}$, M. Nicolaus ${ }^{1}$, I. Peeken ${ }^{1,3}$, K. Bakker ${ }^{4}$, H. Flores ${ }^{1,5}$, and A. Boetius ${ }^{1,2}$ \\ ${ }^{1}$ Alfred Wegener Institute Helmholtz Center for Polar and Marine Research, Bremerhaven, Germany \\ ${ }^{2}$ Max Planck Institute for Marine Microbiology, Bremen, Germany \\ ${ }^{3}$ MARUM, Center for Marine Environmental Sciences, University of Bremen, Bremen, Germany \\ ${ }^{4}$ Royal Netherlands Institute for Sea Research, Texel, the Netherlands \\ ${ }^{5}$ University of Hamburg, Zoological Institute and Zoological Museum, Biocenter Grindel, Hamburg, Germany
}

Correspondence to: M. Fernández-Méndez (mar.fdez.mendez@gmail.com)

Received: 14 December 2014 - Published in Biogeosciences Discuss.: 10 February 2015

Revised: 8 May 2015 - Accepted: 12 May 2015 - Published: 9 June 2015

\begin{abstract}
The ice-covered central Arctic Ocean is characterized by low primary productivity due to light and nutrient limitations. The recent reduction in ice cover has the potential to substantially increase phytoplankton primary production, but little is yet known about the fate of the ice-associated primary production and of the nutrient supply with increasing warming. This study presents results from the central Arctic Ocean collected during summer 2012, when sea-ice extent reached its lowest ever recorded since the onset of satellite observations. Net primary productivity (NPP) was measured in the water column, sea ice and melt ponds by ${ }^{14} \mathrm{CO}_{2}$ uptake at different irradiances. Photosynthesis vs. irradiance (PI) curves were established in laboratory experiments and used to upscale measured NPP to the deep Eurasian Basin (north of $78^{\circ} \mathrm{N}$ ) using the irradiance-based Central Arctic Ocean Primary Productivity (CAOPP) model. In addition, new annual production has been calculated from the seasonal nutrient drawdown in the mixed layer since last winter. Results show that ice algae can contribute up to $60 \%$ to primary production in the central Arctic Ocean at the end of the productive season (August-September). The ice-covered water column has lower NPP rates than open water due to light limitation in late summer. As indicated by the nutrient ratios in the euphotic zone, nitrate was limiting primary production in the deep Eurasian Basin close to the Laptev Sea area, while silicate was the main limiting nutrient at the ice margin near the Atlantic inflow. Although sea-ice cover was substantially reduced in 2012, total annual new production in the Eurasian Basin was $17 \pm 7 \mathrm{TgC}_{\mathrm{yr}}{ }^{-1}$, which is within the
\end{abstract}

range of estimates of previous years. However, when adding the contribution by sub-ice algae, the annual production for the deep Eurasian Basin (north of $78^{\circ} \mathrm{N}$ ) could double pre-

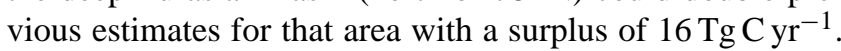
Our data suggest that sub-ice algae are an important component of the productivity in the ice-covered Eurasian Basin of the central Arctic Ocean. It remains an important question whether their contribution to productivity is on the rise with thinning ice, or whether it will decline due to overall sea-ice retreat and be replaced by phytoplankton.

\section{Introduction}

Estimates of annual primary production (PP) in the icecovered central Arctic basins are among the lowest of all oceans worldwide (Sakshaug et al., 2004). On an annual base, the total incoming irradiance and the depth of the winter mixing as a proxy for nutrient stocks are the two main factors that constrain Arctic primary production (Ardyna et al., 2011; Popova et al., 2010). Available irradiance is generally sparse due to the low angle of the sun around the North Pole, and the attenuation effect of sea ice (Sakshaug and Slagstad, 1991). When enough light becomes available for PP between May and September (Arndt and Nicolaus, 2014; Leu et al., 2011), Arctic phototrophs grow in the water column (phytoplankton), in and below sea ice (sea-ice algae) and in melt ponds (melt-pond algae). Light is the main limiting factor for the phytoplankton below thick ice at the beginning of the 


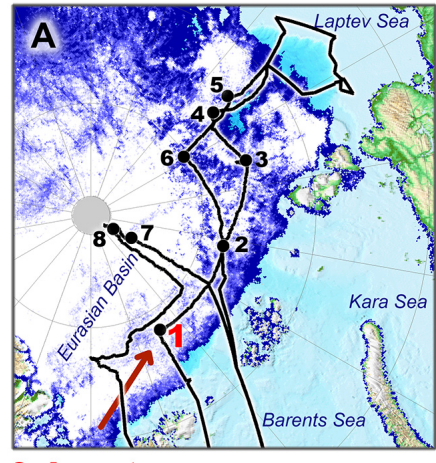

9. August

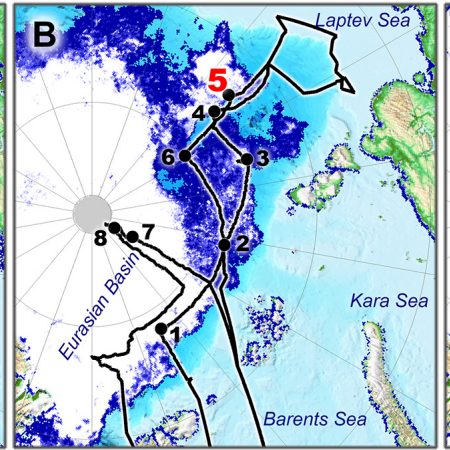

4. September

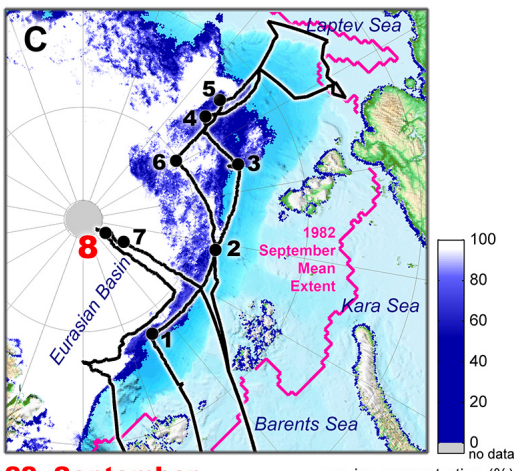

22. September

sea ice concentration (\%)

Figure 1. Cruise track and stations sampled in the Eurasian Basin during summer 2012. The different panels show the sea-ice concentration at the time of sampling the first ice station in early August (a), the fifth station at the beginning of September (b), and the last ice station in early autumn (c). The dates and numbers of those stations are marked in red. The sea-ice extent minimum record was reached in early September 2012 and refreezing started 2 weeks later. For comparison purposes, the mean sea-ice extent for September 1982 is depicted in orange. Water column was sampled every 1 or 2 days during the entire cruise. The exact location of these stations can be seen in Fig. 4.

productive season (Sherr et al., 2003). However, during the summer months the total incoming irradiance increases since daylight is available during $24 \mathrm{~h}$, and sea ice is melting away. North of $78^{\circ} \mathrm{N}$ latitude, the productive season is shorter (June to September) than in southern Arctic regions, since it is restricted by the amount of light penetrating through the dense sea-ice cover (Leu et al., 2011). Nutrients become limiting as the season advances (Tremblay and Gagnon, 2009), due to strong vertical stratification and reduced wind-driven mixing affected by sea ice (Carmack et al., 2006).

The central Arctic Ocean is divided into two deep basins separated by the Lomonosov Ridge: the Eurasian and the Amerasian basins (Fig. 1). These central basins cover $40 \%$ of the Arctic Ocean, but due to their inaccessibility, data for both regions are scarce (Matrai et al., 2013). The two central basins differ in the inflow of waters. Low-salinity, phosphaterich and nitrate-depleted Pacific waters enter the Amerasian Basin through the Bering Strait. Warm, high-salinity Atlantic waters with a higher $\mathrm{N}: \mathrm{P}$ ratio reach the Eurasian Basin through the Fram Strait, but remain submerged under a layer of fresher Arctic surface water for $\sim 5$ years before upwelling (Jones et al., 1998). Since most of the studies regarding nutrient limitation in Arctic waters come from the Amerasian Basin, nitrate is considered the main limiting nutrient for primary production in the central Arctic Ocean (Tremblay and Gagnon, 2009; Tremblay et al., 2012). However, nutrient ratios in the Eurasian Basin are very different to the Amerasian pointing towards silicate limitation rather than nitrate in some regions (Codispoti et al., 2013; Sakshaug et al., 2004; Wheeler et al., 1997). In late summer, mostly regenerated production based on ammonium takes place (Martin et al., 2012). Grazing pressure and the microbial loop also play an important role controlling recycling of nutrients vs. export (Boetius et al., 2013; Olli et al., 2007; Yager et al., 2011), but remain understudied in the central Arctic Ocean.
Sparse sampling, high spatial and temporal variability and the use of different methodologies to estimate PP in and under the ice, as well as in ice-free regions, result in poorly constrained PP values for the central Arctic basins (Miller et al., 2015). These range from $1 \mathrm{TgC}^{-1}$, assuming no production in ice-covered areas (Hill et al., 2013), to $119 \mathrm{Tg} \mathrm{C} \mathrm{yr}^{-1}$ when taking into account the total amount of nutrients used for PP from the mixed layer (Codispoti et al., 2013). The annual areal net primary productivity (NPP) estimates for the Eurasian Basin, including sea-ice algae, range between 10 and $15 \mathrm{~g} \mathrm{C} \mathrm{m}^{-2} \mathrm{yr}^{-1}$, twice as much as in the Amerasian Basin (Codispoti et al., 2013; Gosselin et al., 1997; Sakshaug et al., 2004; Ulfsbo et al., 2014; Wheeler et al., 1996). In the central Arctic Ocean sea-ice algae can contribute up to $57 \%$ of the NPP in summer (Gosselin et al., 1997), but their patchy distribution, the technological challenges in sampling them and the difficulties to obtain in situ estimates of their PP, cause a high uncertainty in the overall estimates (FernándezMéndez et al., 2014; Katlein et al., 2014a).

Recent evidence suggests that the rapid Arctic warming and sea-ice retreat are changing key factors governing primary productivity, especially in the central Arctic basins. The percentage of thick multi-year ice (MYI) has been decreasing rapidly (Laxon et al., 2013; Maslanik et al., 2007; Stroeve et al., 2012), reducing the annual mean ice thickness from 3.6 to $1.2 \mathrm{~m}$ since 1975 (Lindsay and Schweiger, 2015). A summerly ice-free Arctic has been predicted to occur around 2050 (Wang and Overland, 2012). The lowest sea-ice extent since the beginning of recorded observations was reached in September 2012 (NSIDC, 2012) leaving $45 \%$ of the Eurasian Basin north of $78^{\circ} \mathrm{N}$ ice-free $(<15 \%$ ice cover). Furthermore, an increase in melt-pond-covered sea ice has been observed (Rösel and Kaleschke, 2012), enlarging the habitat of phytoplankton and sea-ice algae (Kramer and Kiko, 2011; Lee et al., 2011). All of these changes com- 
Table 1. Physical parameters and autotrophic biomass of the eight ice stations sampled during the expedition ARKXXVII/3 to the Eurasian Basin of the central Arctic during August-September 2012.

\begin{tabular}{|c|c|c|c|c|c|c|c|c|}
\hline Station number & 1 & 2 & 3 & 4 & 5 & 6 & 7 & 8 \\
\hline Station ID & PS80/3_224 & PS80/3_237 & PS80/3_255 & PS80/3_277 & PS80/3_323 & PS80/3_335 & PS80/3_349 & PS80/3_360 \\
\hline Date & 9 Aug 2012 & 14 Aug 2012 & 20 Aug 2012 & 25 Aug 2012 & 4 Sep 2012 & 7 Sep 2012 & 18 Sep 2012 & 22 Sep 2012 \\
\hline Latitude & $84^{\circ} 3.03^{\prime} \mathrm{N}$ & $83^{\circ} 59.19^{\prime} \mathrm{N}$ & $82^{\circ} 40.24^{\prime} \mathrm{N}$ & $82^{\circ} 52.95^{\prime} \mathrm{N}$ & $81^{\circ} 55.53^{\prime} \mathrm{N}$ & $85^{\circ} 6.11^{\prime} \mathrm{N}$ & $87^{\circ} 56.01^{\prime} \mathrm{N}$ & $88^{\circ} 49.66^{\prime} \mathrm{N}$ \\
\hline Longitude & $31^{\circ} 6.83^{\prime} \mathrm{E}$ & $78^{\circ} 6.20^{\prime} \mathrm{E}$ & $109^{\circ} 35.37^{\prime} \mathrm{E}$ & $130^{\circ} 7.77^{\prime} \mathrm{E}$ & $131^{\circ} 7.72^{\prime} \mathrm{E}$ & $122^{\circ} 14.72^{\prime} \mathrm{E}$ & $61^{\circ} 13.04^{\prime} \mathrm{E}$ & $58^{\circ} 51.81^{\prime} \mathrm{E}$ \\
\hline Incoming PAR ( $\mu \mathrm{mol}$ photons $\mathrm{m}^{-2} \mathrm{~s}^{-1}$ ) & $249 \pm 90$ & $174 \pm 90$ & $104 \pm 71$ & $101 \pm 57$ & $81 \pm 63$ & $49 \pm 43$ & $25 \pm 15$ & $13 \pm 7$ \\
\hline Ice cover & $80 \%$ & $80 \%$ & $70 \%$ & $80 \%$ & $60 \%$ & $50 \%$ & $100 \%$ & $100 \%$ \\
\hline Ice thickness (m) & 1.2 & 1.2 & 0.9 & 0.9 & 0.8 & 1.4 & 1.9 & 1.8 \\
\hline Ice type (FYI/MYI) & FYI & FYI & FYI & FYI & FYI & FYI & MYI & MYI \\
\hline Melt-pond coverage (\%) & $40 \%$ & $20 \%$ & $40 \%$ & $50 \%$ & $10 \%$ & $30 \%$ & $20 \%$ & $20 \%$ \\
\hline Melt-pond depth (m) & 0.6 & 0.2 & 0.3 & 0.4 & 0.3 & 0.2 & 0.3 & 0.3 \\
\hline Melt-pond salinity & 18 & 1 & 0.5 & 2 & 14 & 0.4 & 30 & 12 \\
\hline Euphotic zone depth (m) & 24 & 29 & 30 & 29 & 33 & 29 & 15 & 7 \\
\hline Euphotic zone Chl $a\left(\mathrm{mg} \mathrm{m}^{-2}\right)$ & 3.2 & 17 & 8 & 8 & 11 & 17 & 3 & 1.2 \\
\hline Sea-ice Chl $a\left(\mathrm{mg} \mathrm{m}^{-2}\right)$ & 1.2 & 1.7 & 0.6 & 0.4 & 0.3 & 0.4 & 8 & 8 \\
\hline Melt-pond Chl $a\left(\mathrm{mg} \mathrm{m}^{-2}\right)$ & 0.3 & 0.02 & 0.1 & 0.02 & 0.1 & 0.02 & 0.3 & 0.04 \\
\hline
\end{tabular}

Ice was classified in two types: first year (FYI) and multi-year (MYI) according to its structure and physical properties. The euphotic zone depth is a weighted average of the euphotic zone depth below bare ice, ponded ice and open water at each station. Chlorophyll $a(\mathrm{Chl} a)$ was integrated for the melt-pond depth, the sea ice $\sim 600$ could be applied to obtain carbon units (Laney et al., 2014).

bined lead to an increase in the amount of irradiance reaching the water column in the central Arctic Ocean (Nicolaus et al., 2012). On the other hand, nutrient availability in the euphotic zone of the deep central Arctic Ocean may decrease due to the stronger stratification caused by increased freshwater storage. An increase in nutrients from river runoff has been hypothesized, but a recent study by Le Fouest et al. (2013) indicates that these nutrients will not be enough to increase primary production in the deep central Arctic substantially, since they will be consumed at the shelf seas. Furthermore, changes in light conditions and nutrient availability might affect the timing of sea ice and water column blooms and the composition of the autotrophic biomass; this will have implications for timing and food quality available for grazers (Leu et al., 2010; Slagstad et al., 2011) and for total export to the deep sea (Lalande et al., 2013).

This study assesses primary productivity in the Eurasian Basin of the central Arctic Ocean at the time of the sea-ice minimum extent in summer 2012, in comparison to previous estimates. It aims to quantify the relative contribution of sea ice, melt ponds and water column to total NPP, both in situ and for the entire Eurasian Basin, with a focus on the bottom-up limiting factors of NPP (light and nutrients) at different timescales. Using complementary approaches we test the hypothesis that primary productivity - including that of under-ice algae - could increase with decreasing ice cover in the central Arctic Ocean.

\section{Methods}

\subsection{Study site and sampling}

Sea ice, melt ponds and water column were sampled during the R/V Polarstern expedition ARK-XXVII/3 to the Eurasian Basin of the central Arctic Ocean during summer 2012. The expedition started in early August visiting the ice margin and heading towards the Laptev Sea (Fig. 1a). At the beginning of September the ice-free shelf edge of the Laptev Sea $\left(77-80^{\circ} \mathrm{N}, 118-133^{\circ} \mathrm{E}\right)$ was sampled (Fig. 1b) and at the end of the month the central Arctic was reached (85$88^{\circ} \mathrm{N}, 52-123^{\circ} \mathrm{E}$ ) (Fig. 1c). The expedition covered a large portion of the Eurasian Basin and included 33 water stations in Atlantic-influenced waters entering the Arctic through Fram Strait (Atlantic inflow as described in Rudels, 2012), as well as eight ice stations expanding through different nutrient regimes, ice coverage (from ice-free waters to $100 \%$ ice cover) and ice types according to age, thickness, pond and snow cover and topography. First year ice (FYI) was rather flat with a high coverage of melt ponds and MYI is thicker and has more snow on top (Table 1).

Sea-ice concentration and melt-pond coverage were assessed during the entire cruise by observations from the bridge (Hendricks et al., 2012) (Table S1 in the Supplement). Sea-ice thickness was additionally measured with an airborne electromagnetic (EM) bird as described in Haas et al. (2009). Sea ice was sampled using an ice corer $(9 \mathrm{~cm}$ diameter) (Kovacs Enterprise, Roseburg, USA). Ice cores were cut into two equal sections (top and bottom) for primary productivity measurements and in $10 \mathrm{~cm}$ sections for biomass and nutrient measurements. Ice cores were melted in the dark at $4{ }^{\circ} \mathrm{C}$ for $24 \mathrm{~h}$ on a shaker (Mikkelsen et al., 2008; Rintala et al., 2014). Seawater from 50 to $100 \mathrm{~m}$ depth from a nearby station filtered through a $0.2 \mu \mathrm{m}$ filter $(200 \mathrm{~mL}$ per $\mathrm{cm}$ of ice) was added to the ice sections used for pigment analysis (Thomas and Dieckmann, 2010).

Melt-pond water samples were obtained with a hand pump (Model 6132-0010, Nalgene, Penfield, NY, USA) and meltpond depth, temperature and salinity were measured in situ using a hand-held conductivity metre (315i with TetraCon electrode cell, WTW GmbH, Weilheim in Oberbayern, Germany). Water column profiles of temperature and salinity were obtained using a conductivity-temperature-depth 
(CTD) system with a Carousel Water Sampler (Sea-Bird Electronics Inc., Washington, USA). Water below the ice was sampled using a peristaltic pump (Masterflex ${ }^{\circledR} \mathrm{E} / \mathrm{S}^{\mathrm{TM}}$ portable sampler, $115 \mathrm{VAC}$, Oldham, UK), while water samples in ice-free areas were collected at $2-5 \mathrm{~m}$ depth during the upcast of the CTD rosette sampler. Flow cytometer samples showed no evident difference in relation to either sampling method. To exclude the effect of propeller mixing in the upper $20 \mathrm{~m}$ of CTD profiles, additional vertical profiles of under ice salinity, temperature and fluorescence were obtained by manually lowering a CTD probe through holes in the ice floes sampled (ice CTD; Sea and Sun Technology CTD75M, Trappenkamp, Germany). Fluorescence in the water column was measured with two fluorometers (Turner Cyclops, California, USA) attached to the ship CTD and the iceCTD. Fluorescence values were calibrated a posteriori with chlorophyll $a(\mathrm{Chl} a)$ concentrations from water samples using high-performance liquid chromatography (HPLC) as described in Tran et al. (2013) and David et al. (2015). Chl $a$ in the ice and melt ponds was measured using the same HPLC method.

For the nutrient addition experiments, $20 \mathrm{~L}$ of seawater was collected at station 3 at the depth of the maximum Chl $a$ concentration $(25 \mathrm{~m})$ using the ship's CTD sampler, and a piece of sea ice $(40 \mathrm{~cm} \times 40 \mathrm{~cm})$ was cut with an ice saw at station 8 and melted in the dark in $0.2 \mu \mathrm{m}$ filtered seawater from the same location (Rozanska et al., 2009; Thomas and Dieckmann, 2010).

\subsection{In situ net primary production}

Net primary production (NPP) was measured using the ${ }^{14} \mathrm{C}$ uptake method (Steemann Nielsen, 1952) with minor modifications. Melted sea ice, seawater and melt-pond samples were spiked with $0.1 \mu \mathrm{Ci} \mathrm{mL}^{-1}$ of ${ }^{14} \mathrm{C}$, labelled sodium bicarbonate (Moravek Biochemicals, Brea, USA) and distributed in 10 clear bottles ( $20 \mathrm{~mL}$ each). Subsequently they were incubated for $12 \mathrm{~h}$ at $-1.3^{\circ} \mathrm{C}$ under different scalar irradiances $\left(0-420 \mu \mathrm{mol}\right.$ photons $\left.\mathrm{m}^{-2} \mathrm{~s}^{-1}\right)$ measured with a spherical sensor (Spherical Micro Quantum Sensor USSQS/L, Heinz Walz, Effeltrich, Germany). At the end of the incubation, samples were filtered onto $0.2 \mu \mathrm{m}$ nitrocellulose filters and the particulate radioactive carbon uptake was determined by liquid scintillation counting using filter count scintillation cocktail (Perkin Elmer, Waltham, USA). The carbon uptake values in the dark were subtracted from the carbon uptake values measured in the light incubations.

Dissolved inorganic carbon (DIC) was measured for each sample using the flow injection system (Hall and Aller, 1992). The DIC concentration was taken into account to calculate the amount of labelled bicarbonate incorporated into the cell. Carbon fixation rates were normalized volumetrically and by Chl $a$ (doi:10.1594/PANGAEA.834221). Photosynthesis-irradiance curves (PI curves) were fitted using MATLAB ${ }^{\circledR}$ according to the equation proposed by Platt et al. (1980) including a photoinhibition parameter $(\beta)$ and providing the main photosynthetic parameters: maximum Chl $a$ normalized carbon fixation rate if there was no photoinhibition $\left(P^{b}\right)$ and the initial slope of the saturation curve $(\alpha)$. The derived parameters, light intensity at which photosynthesis is maximal $\left(I_{\mathrm{m}}\right)$, the carbon fixation rate at that maximal irradiance $\left(P_{\mathrm{m}}^{b}\right)$ and the adaptation parameter or photoacclimation index $\left(I_{k}\right)$, were calculated according to Platt et al. (1982) (Table 2).

Depth-integrated in situ rates were calculated for each environment as a function of the available photosynthetically active radiation (PAR). Irradiance profiles were calculated for each environment (sea ice, melt pond, water under the ice and open water) from the daily average incoming solar shortwave irradiance measured by a pyranometer (Kipp \& Zonen, Delft, the Netherlands) mounted on the ship. We used light attenuation coefficients of $10 \mathrm{~m}^{-1}$ for snow, $1.5 \mathrm{~m}^{-1}$ for sea ice (Perovich, 1996) and $0.1 \mathrm{~m}^{-1}$ for Atlantic-influenced Arctic seawater, based on literature values and observations during the cruise. Planar irradiance was transformed to scalar irradiance according to Ehn and Mundy (2013) and Katlein et al. (2014). Water column production was integrated over the euphotic zone (1\% of incoming irradiance) and sea-ice production over the ice thickness. Melt-pond coverage and sea-ice concentration (Table 1) were taken into account when calculating the total primary production per area.

\subsection{Central Arctic Ocean Primary Productivity model}

We developed the Central Arctic Ocean Primary Productivity (CAOPP) model as an irradiance-based model to obtain estimates of sea ice, melt pond and water column NPP in the central Arctic (north of $78^{\circ} \mathrm{N}$ ). This model is based on the photosynthesis equation from Platt et al. (1980) and the underice light parameterization of Arndt and Nicolaus (2014). Average Chl $a$ profiles and average PI curves were calculated for each environment (Fig. 2): melt ponds (MP), MYI, FYI, water under the ice (WUI) and open water (OW). Key parameters for photosynthetic activity (Table 2) were calculated from the measured PI curves during summer 2012, excluding those where the coefficient of determination of the fit $\left(R^{2}\right)$ was smaller than 0.5. NPP was calculated as described in Sect. 2.2 for each grid point of a $10 \mathrm{~km}$ polar stereographic grid, and a vertical integration with a resolution of $10 \mathrm{~cm}$ in the ice and $1 \mathrm{~m}$ in the water column. Downwelling solar irradiances at the surface (PAR) were calculated from the European Centre for Medium-Range Weather Forecast (ECMWF) Era Interim re-analyses (Dee et al., 2011). Downwelling transmitted irradiances underneath the sea ice were calculated using the light parameterization of Arndt and Nicolaus (2014) based on sea-ice data from Ocean and Sea Ice Satellite Application Facility (OSISAF) (Andersen et al., 2007). Light extinction in all media was assumed to follow an exponential decay. For water and sea ice we used the same light extinction coefficients as presented above. NPP was cal- 

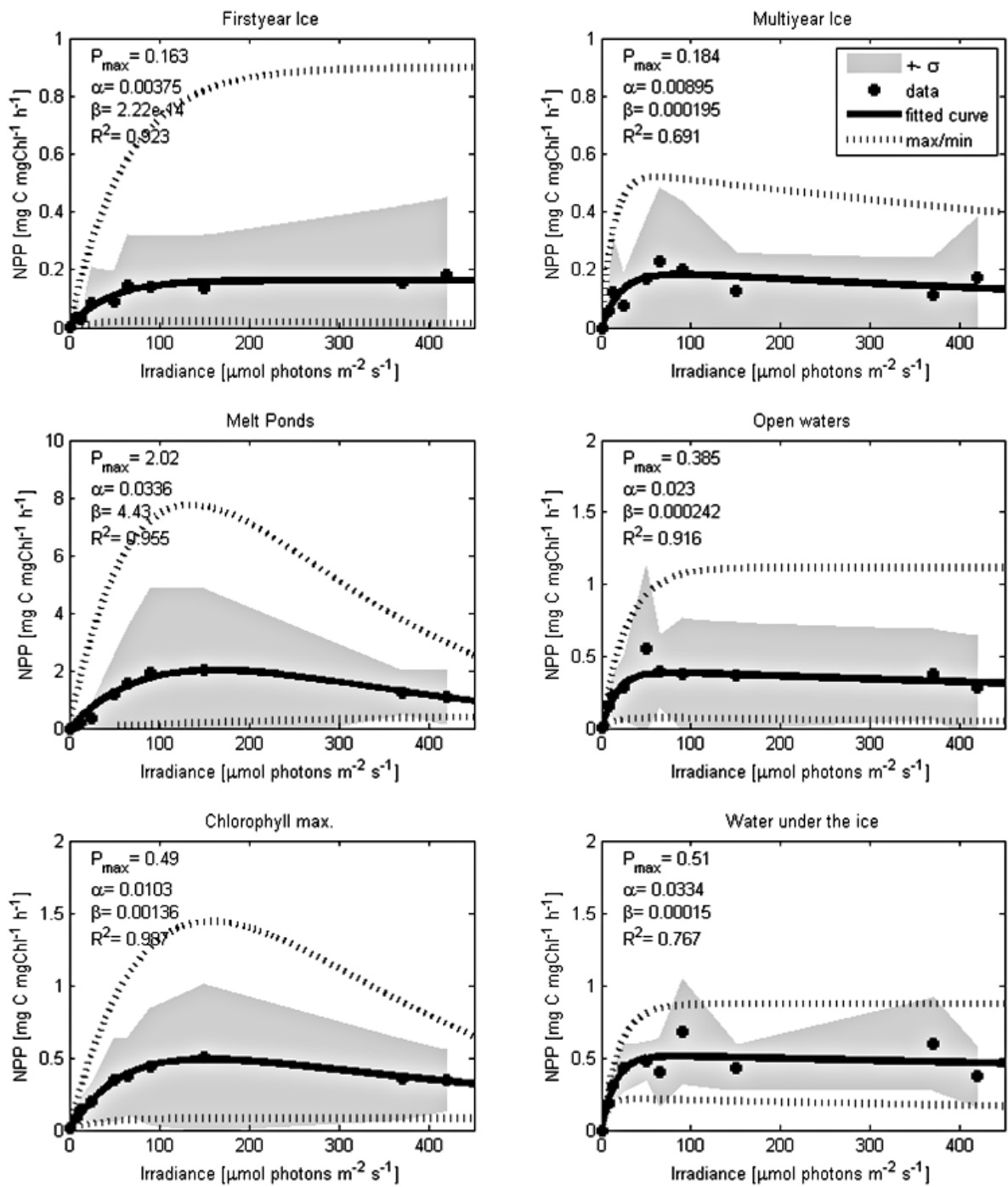

Figure 2. Average photosynthesis versus irradiance curves (PI curve) for each environment. The average fitted curve and the photosynthetic parameters derived from it were used to calculate the in situ primary production in each environment during August and September for the Eurasian Basin using the irradiance-based CAOPP model. The dots represent the experimental measurements, the black solid line is the fitted curve, the dashed lines are the minimum and the maximum, and the grey shaded area is the standard deviation. Average PI parameters are represented on the top left corner.

culated as a function of PAR for every depth multiplied with the according Chl $a$ concentration and integrated over the euphotic zone ( $1 \%$ incoming PAR). For pixels with a sea-ice concentration $>15 \%$, the WUI average PI curve was used, while for pixels with $<15 \%$ sea-ice concentration the OW average PI curve was used. Note that the OW average PI curve is based on data obtained close to the Laptev Sea area. For melt ponds, an average depth of $0.4 \mathrm{~m}$ was used based on observations during the expedition (Hendricks et al., 2012). Since satellite-based melt-pond cover data were not available for summer 2012, a constant melt-pond concentration was used for FYI (26\%) and for MYI (29\%) following Arndt and Nicolaus (2014) and Rösel and Kaleschke (2012). These values are similar to the average melt-pond coverage observed during our cruise (30 $\pm 15 \%)$ (Hendricks et al., 2012). Total depth-integrated NPP (INPP) was calculated as an average of the three compartments, i.e. open water, water covered by sea ice and water covered by sea ice with melt ponds, weighted with the respective areal fraction. To estimate the total range of INPP, we ran the CAOPP model three times using the average, the minimum and the maximum photosynthetic parameters.

To investigate differences in NPP in different sectors of the deep Eurasian Basin due to changes in the sea-ice conditions, we ran the model under two different scenarios: one with sea-ice conditions previous to the rapid sea-ice decline in the 1980s and another one with no sea-ice cover in summer. For the first scenario, we chose 1982 as a representative year 


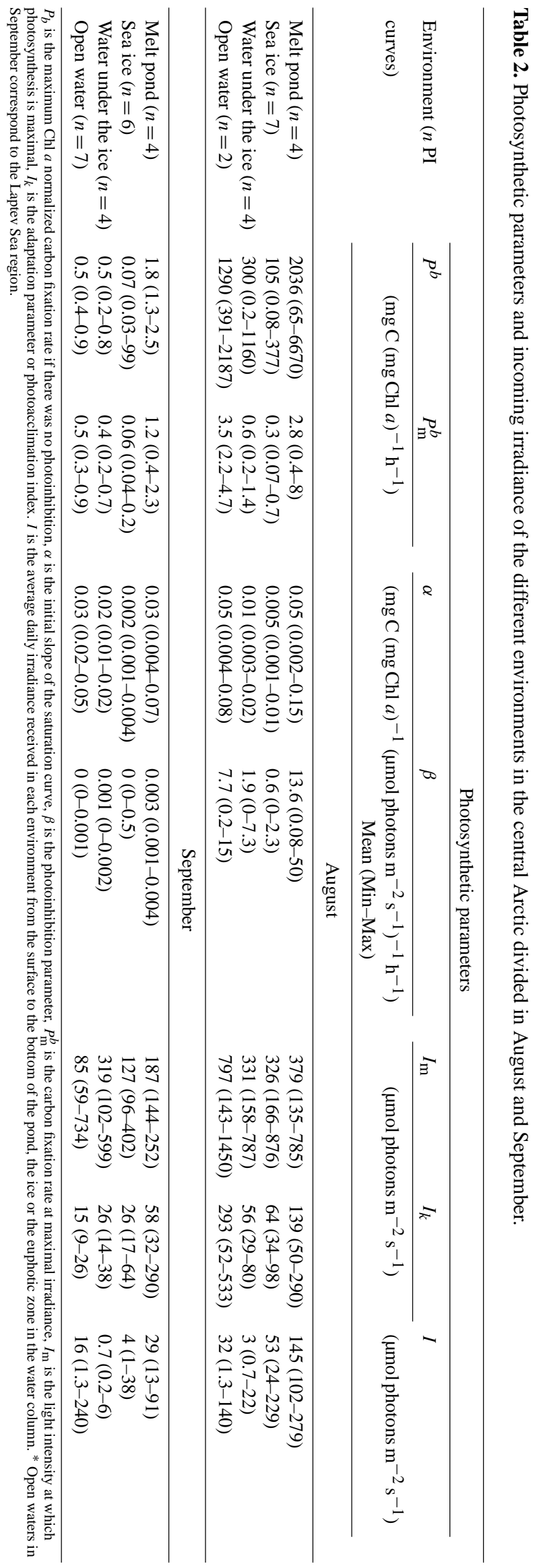

previous to the long-term trend of sea-ice decline (Fig. 1c). For the second scenario we chose a summer ice-free scenario that has been predicted to occur around 2050 (Wang and Overland, 2012). For the 1982 scenario, the sea-ice coverage information was retrieved from OSI SAF (Andersen et al., 2007) and the incoming irradiance from data re-analysis (Arndt and Nicolaus, 2014). For the ice-free scenario, the ice cover was removed from the model, and all other parameters, including incoming irradiance, were kept as in 2012. Both scenarios assume no changes in the photosynthetic parameters, and the nutrient concentrations were set as observed in 2012. The mean results for September 1982, 2012 and 2050 are compared in Table 5 to detect the increasing or decreasing trend in NPP.

\subsection{Nutrient addition experiments}

Two nutrient addition experiments were performed during the cruise at ice stations 3 and 8 (Fig. 1). For the first one, seawater from the depth of the Chl $a$ maximum $(25 \mathrm{~m})$ was collected, and for the second one, MYI with a brown coloration due to the high content of sea-ice algae was melted in filtered seawater taken at the same spot. Both samples were pre-filtered through a $100 \mu \mathrm{m}$ mesh to remove grazers and kept at $0^{\circ} \mathrm{C}$ and $65 \mu \mathrm{mol}$ photons $\mathrm{m}^{-2} \mathrm{~s}^{-1}$ in $25 \mathrm{~L}$ transparent bottles until the start of the experiment. Chl $a$ was monitored every day with a Turner Trilogy Fluorometer (model 7200-000) (Turner, California, USA) to identify the end of a possible lag effect. Once $\mathrm{Chl} a$ reached a stable concentration (6 days for seawater and 4 days for sea ice) the sample was mixed and distributed in 10 transparent $5 \mathrm{~L}$ Nalgene bottles ( $2 \mathrm{~L}$ in each). The initial biomass concentration in the samples was estimated by measuring Chl $a$ and particulate organic matter. A sub-sample $(0.5 \mathrm{~L})$ was filtered through a pre-combusted glass fiber filter (GF/F) $(0.7 \mu \mathrm{m}$ pore size, Whatman, Kent, UK) and analysed with an elemental analyser (EA3024-IRMS, EuroVetorSpA, Milan, Italy) to quantify particulate organic carbon (POC) and particulate organic nitrogen (PON). For Chl $a$ quantification a sub-sample $(0.5 \mathrm{~L})$ was filtered through a GF/F filter and the pigments were extracted with $90 \%$ acetone during $24 \mathrm{~h}$ (Parsons et al., 1984). The fluorescence was then measured with a Turner Fluorometer (Turner, California, USA).

Nutrient concentrations (nitrate, phosphate and silicate) were measured with a standard photometric method using a Technicon TRAACS 800 continuous flow auto-analyser (Technicon Corporation) according to established methods (Boetius et al., 2013). Five different treatments in duplicate were incubated at $75 \mu \mathrm{mu}$ mol photons $\mathrm{m}^{-2} \mathrm{~s}^{-1}$. This irradiance is slightly higher than the average irradiance below the ice at the end of the productive season to avoid light limitation and prevent photoinhibition. The five treatments consisted of a control with no nutrient addition (C), a positive control with the three nutrients added $(\mathrm{C}+)$ and three treatments with one nutrient added in each $(\mathrm{N}+, \mathrm{P}+$ and 
$\mathrm{Si}+$ ). In each treatment, the added nutrient concentration resembled the concentration of that nutrient in deep waters $(>100 \mathrm{~m})$ at the same ice station. Biomass (Chl $a, \mathrm{POC}$ and PON) and nutrients were measured in each treatment after 2 days and compared to the initial value. In parallel a subset of four samples $(20 \mathrm{~mL}$ each) from each treatment were spiked with ${ }^{14} \mathrm{C}$ bicarbonate to estimate NPP as described above. Three samples were incubated under light conditions ( $75 \mu \mathrm{mol}$ photons $\mathrm{m}^{-2} \mathrm{~s}^{-1}$ ) and one in the dark for $24 \mathrm{~h}$. Previous to incubation and at the end of the experiments the qualitative algal composition from each treatment was studied with a plankton chamber (Hydro-Bios, Altenholz, Germany) and an inverted light microscope with phase contrast optics (Axiovert 40C, Carl Zeiss, Jena, Germany) with an integrated camera (AxioCamMRc, Carl Zeiss, Jena, Germany). No qualitative shifts in the community composition were observed before or after the incubation.

\subsection{Annual new production}

We determined the mixed layer depth during the previous winter from temperature in our summer CTD profiles of the upper Arctic Ocean, following Rudels (1995) and Korhonen et al. (2013). In the temperature profiles during the Arctic Ocean melting season, the winter mixed layer depth is indicated by a temperature minimum above the lower halocline. Any conservative property, such as salinity, observed at the depth of this temperature minimum, represents the conditions of the mixed layer during the previous winter. An estimate of the change from the previous winter is given by the difference between a conservative property in summer and its reference value at the depth of the temperature minimum. The vertical integral of these differences represents the addition or removal of a quantity or substance, for example nitrate, since the previous winter. All oceanographic data used in this study are available from the Earth system database PANGAEA (Rabe et al., 2012) (Table S1).

Nutrients (phosphate, silicate and nitrate) in the water column were measured at discrete depths $(2,10,20,30$, 50,75 and $100 \mathrm{~m}$ ) as described above (Bakker, 2014) (Table S1). Subsequently, we interpolated total inorganic nitrogen $\left(\mathrm{TIN}=\mathrm{NO}_{3}^{-}+\mathrm{NO}_{2}^{-}\right.$), phosphate and silicate to the vertical resolution of the continuous temperature profiles (Reiniger et al., 1968), to calculate the nutrient inventory in the layer above the temperature minimum. We then derived the uptake since last winter by calculating the difference between the integrated nutrient profile at the end of the productive season (August-September) and the nutrient value at the temperature minimum depth, which represents the initial nutrient concentration available in winter in the mixed layer. This approach is similar to the one used by Codispoti et al. (2013) with the main difference that they used the few available winter surface nutrient concentrations. The annual TIN, phosphate and silicate uptake were then transformed to carbon units using the Redfield ratio $106 \mathrm{C}: 16 \mathrm{~N}: 15 \mathrm{Si}: 1 \mathrm{P}$
(Brzezinski, 1985; Codispoti et al., 2013; Cota et al., 1996; Harrison et al., 1977; Smith et al., 1997) giving annual new production estimates for sea ice and water column during the Arctic productive season. Since the description of new production refers to production based on nitrate, most of the annual new production estimates are based on nitrogen drawdown (Dugdale and Goering, 1967). Ratios higher than the Redfield C: N ratio (7.3-8.3) seem to be common in Arctic phytoplankton and sinking material (Frigstad et al., 2014; Tamelander et al., 2013; Tremblay et al., 2008). Using these ratios would result in a $\sim 10 \%$ increase in the new production estimates, but to be able to compare our results with previous estimates we chose the commonly used Redfield ratio. Silicate can also be used to estimate diatom-based new production (Yool et al., 2007). Both higher and lower N : Si ratios have been reported for Arctic diatoms (Simpson et al., 2013; Spilling et al., 2010) depending on the time of the year and the amount of detritus material present. To be consistent with the nitrogen-based estimates, we used Redfield ratios for silicate as well. To calculate an average daily rate, we assumed a productive season of 120 days (Gradinger et al., 1999). This method assumes that lateral input of nutrients from rivers or shelves is negligible which should be the case in the deep part of the central Arctic Ocean north of $78^{\circ} \mathrm{N}$ (Le Fouest et al., 2013).

\section{Results}

\subsection{Environmental conditions}

Sea ice, melt ponds, and water column environments were sampled in the Eurasian Basin in August and September 2012 at the end of the productive season, including completely and partially ice-covered areas above the abyssal basins as well as open waters on the Eurasian shelf. From the eight ice stations sampled, stations 1, 2 and 3 represent the ice margin (Nansen Basin) in early August (Fig. 1a); 4,5 and 6 represent the degraded ice cover (average $1 \mathrm{~m}$ thickness) above the continental slope of the Eurasian margin (Fig. 1b), and 7 and 8 represent MYI (average $1.8 \mathrm{~m}$ thickness) in the central Arctic Ocean (Amundsen Basin) in late September (Fig. 1c). In September, a thin snow cover of 0.02 and $0.06 \mathrm{~m}$ thickness was observed. Melt-pond cover varied between 10 and $50 \%$, and from mid-September most of the melt ponds were frozen over $(<0.1 \mathrm{~m}$ ice thickness). Salinity in the ice (0-4) and the water column (3034) were in typical ranges for these environments, while steep gradients were found in melt ponds (vertical gradients of 0.4 at the surface to 32 at the bottom) and also between different melt ponds, depending if they were open to the seawater below or closed. The daily mean incoming irradiance showed a strong temporal decrease from a $24 \mathrm{~h}$ average of $250 \mu \mathrm{mol}$ photons $\mathrm{m}^{-2} \mathrm{~s}^{-1}$ in early August to $13 \mu \mathrm{mol}$ photons $\mathrm{m}^{-2} \mathrm{~s}^{-1}$ in late September. In the water col- 
Table 3. Nutrient inventories and molar ratios in each environment during summer 2012 separated into the three nutrient regimes observed.

\begin{tabular}{|c|c|c|c|c|c|}
\hline & \multicolumn{5}{|c|}{ Nutrients } \\
\hline & \multirow[t]{2}{*}{ Nitrate } & \multirow{2}{*}{$\begin{array}{c}\text { Phosphate } \\
\left(\mathrm{mmol} \mathrm{m}^{-2}\right)\end{array}$} & \multirow{2}{*}{ Silicate } & $\mathrm{N}: \mathrm{P}$ & $\mathrm{N}: \mathrm{Si}$ \\
\hline & & & & \multicolumn{2}{|c|}{$\mathrm{mol}: \mathrm{mol}$} \\
\hline & \multicolumn{5}{|c|}{ Ice margin (6-18 August 2012) } \\
\hline Melt pond $(n=2)$ & $0.1-0.8$ & $0-0.12$ & $0.01-1.6$ & $6.8-85$ & $0.5-9$ \\
\hline Sea ice $(n=2)$ & $0.3-0.8$ & $0.03-1.3$ & $0.2-0.5$ & $0.6-11$ & $0.6-4$ \\
\hline \multirow{2}{*}{ Seawater $(n=9)$} & $76-157$ & $7-16$ & $27-77$ & $9-11$ & $1.7-2.8$ \\
\hline & \multicolumn{5}{|c|}{ Laptev Sea (20 August-10 September 2012) } \\
\hline Melt pond $(n=4)$ & $0.2-0.4$ & $0-0.15$ & $0.1-0.8$ & $2-114$ & $0.4-5$ \\
\hline Sea ice $(n=4)$ & $0.2-0.7$ & $0.01-0.06$ & $0.1-0.4$ & $5.2-15$ & $0.6-4$ \\
\hline \multirow[t]{2}{*}{ Seawater $(n=17)$} & $8-126$ & $4.5-19$ & $35-220$ & $1.2-8.6$ & $0.1-1$ \\
\hline & \multicolumn{5}{|c|}{ North of $85^{\circ} \mathrm{N}$ (18-27 September 2012) } \\
\hline Melt pond $(n=2)$ & $0.06-0.2$ & $0.01-0.06$ & $0.1-0.9$ & $1-18.3$ & $0.2-0.5$ \\
\hline Sea ice $(n=2)$ & $0.2-1.7$ & $0.04-0.1$ & $0.1-0.2$ & $4.7-17$ & $1-16$ \\
\hline Seawater $(n=6)$ & $4-31.0$ & $1.5-3.5$ & $12-23$ & $3-9$ & $0.3-1.7$ \\
\hline
\end{tabular}

Nutrient concentrations in $\mathrm{mol} \mathrm{L}^{-1}$ are available in PANGAEA (doi in Table $\mathrm{S} 1$ in the Supplement).

Nutrient concentrations were integrated for melt-pond depth, sea-ice thickness and water column euphotic zone ( $1 \%$ incoming PAR).

A

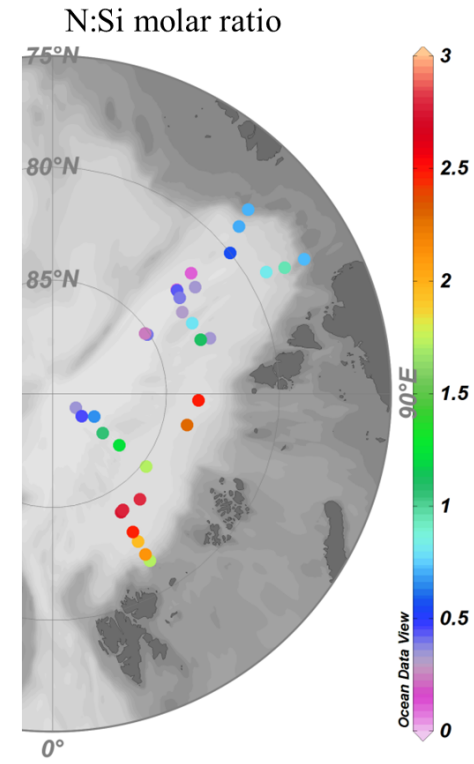

B

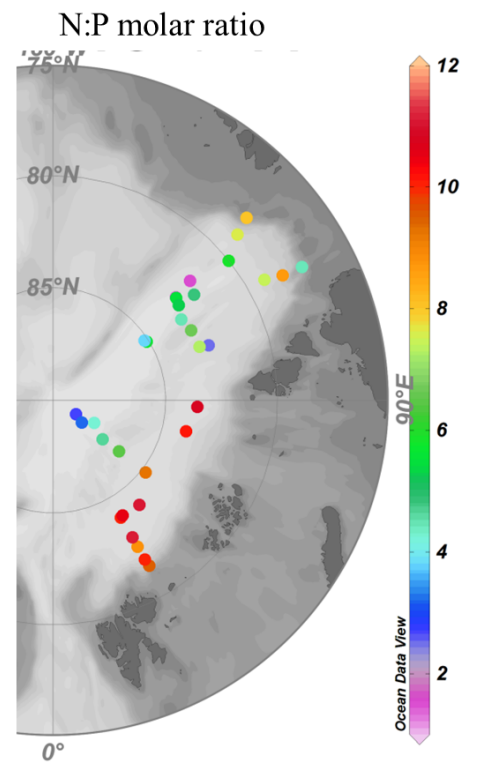

Figure 3. $\mathrm{N}: \mathrm{Si}$ and $\mathrm{N}: \mathrm{P}$ molar ratios in the euphotic zone of the water column during summer 2012. In (a), the light blue-green range represents N : Si ratios optimal for diatom growth, red marks an excess of N, blue-purple represents depletion. In (b), all values are below the $\mathrm{N}$ : P Redfield ratio of 16 indicating a general nitrate depletion with respect to phosphate.

umn directly below the ice, photosynthetically active radiation (PAR) decreased from $40 \mu \mathrm{mol}$ photons $\mathrm{m}^{-2} \mathrm{~s}^{-1}$ in early August to $1 \mu \mathrm{mol}$ photons $\mathrm{m}^{-2} \mathrm{~s}^{-1}$ in late September.

Integrated nutrient inventories were very low in all environments in accordance with the time of the year (Table 3). Nutrient distributions in the euphotic zone of the water column were reflected in the $\mathrm{N}: \mathrm{P}$ and $\mathrm{N}: \mathrm{Si}$ ratios
(Fig. 3) leading to the characterization of three distinct nutrient regimes in the Eurasian Basin during the cruise: (1) silicate-depleted ice margin in early August, (2) nitratedepleted Laptev Sea margin, and (3) all nutrient-depleted high central Arctic Ocean (north of $85^{\circ} \mathrm{N}$ ) in late September (Fig. 4; Table 3). Nutrient depletion is defined here as 


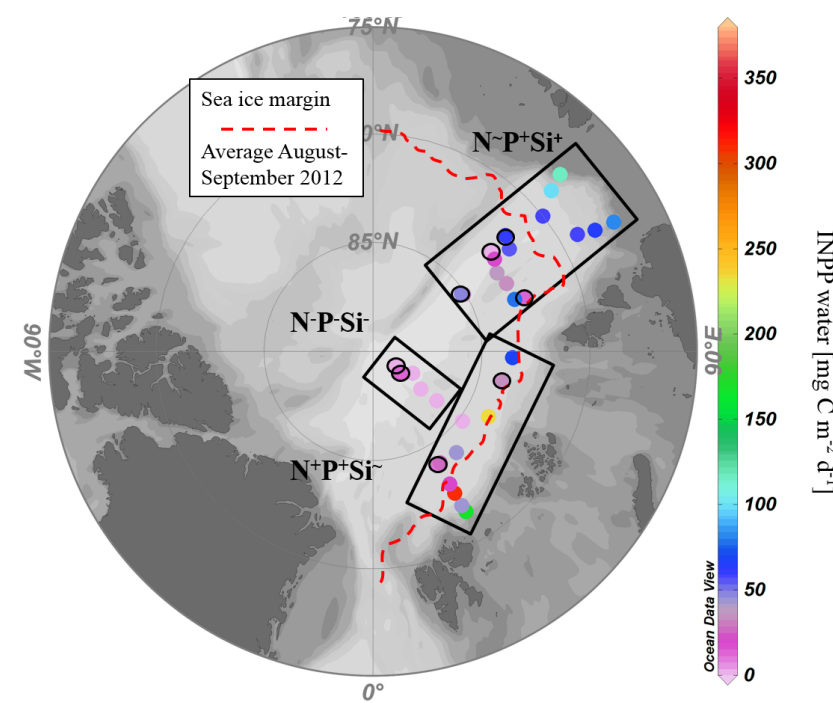

Figure 4. Integrated net primary productivity (INPP) in the water column of the central Arctic Eurasian Basin in AugustSeptember 2012. The eight ice stations are circled with a black line. The three boxes indicate different nutrient regimes characterized by the concentrations of nitrate $(\mathrm{N})$, phosphate $(\mathrm{P})$ and silicate $(\mathrm{Si})$ in the water column. The superscripts on each nutrient indicate if there was high $(+)$, medium $(\sim)$ or low $(-)$ amounts of that nutrient in the euphotic zone. High is defined as concentrations of nitrate $>3 \mu \mathrm{M}$, phosphate $>0.3 \mu \mathrm{M}$, and silicate $>3 \mu \mathrm{M}$. Low or depleted is defined as concentrations of nitrate $<1 \mu \mathrm{M}$, phosphate $<0.2 \mu \mathrm{M}$ and silicate $<1.5 \mu \mathrm{M}$.

concentrations lower than $1 \mu \mathrm{mol} \mathrm{L}-1$ nitrate, $0.2 \mu \mathrm{mol} \mathrm{L}-1$ phosphate, and $1.5 \mu \mathrm{mol} \mathrm{L}^{-1}$ silicate.

\subsection{Photosynthesis and irradiance}

Despite the high spatial and temporal variability present in our data set, certain patterns emerged when comparing the photosynthetic parameters of sea-ice algae, melt-pond phototrophs and water column phytoplankton (Table 2). A general decrease in all photosynthetic parameters was detected between August and September. However, the low number of samples and the wide area sampled makes it difficult to further differentiate the photosynthetic parameters. Sea-ice algae showed the best adaptation to low light (initial slope of the PI curve $\alpha$ ). Photoinhibition ( $\beta$ ) was lower in sea-ice algae than in melt-pond phototrophs and under-ice phytoplankton, but higher than for phytoplankton in ice-free waters (Table 2). In late summer (August and September), seaice algae were adapted to light intensities between 20 and $100 \mu \mathrm{mol}$ photons $\mathrm{m}^{-2} \mathrm{~s}^{-1}$, similar to the under-ice phytoplankton $\left(14-80 \mu \mathrm{mol}\right.$ photons $\left.\mathrm{m}^{-2} \mathrm{~s}^{-1}\right)$. These irradiances were generally higher than the average irradiance available under the ice $\left(0.2-20 \mu \mathrm{mol}\right.$ photons $\mathrm{m}^{-2} \mathrm{~s}^{-1}$, Table 2). Phytoplankton showed higher photoinhibition below the ice than in ice-free waters. Furthermore, in September under-ice phy- toplankton showed a higher range of light intensities at which photosynthesis is maximal $\left(I_{\mathrm{m}}\right)$ than phytoplankton in open waters. Melt-pond phototrophs and phytoplankton in open waters close to the ice margin in early August reached the highest carbon fixation rates $\left(P_{\mathrm{m}}^{b}\right)$. However, they also showed the highest photoinhibition rates at high irradiances (Table 2), despite being adapted to higher irradiances $\left(I_{k}\right.$ : 50-290 $\mu$ mol photons $\mathrm{m}^{-2} \mathrm{~s}^{-1}$ ) than sea-ice algae and phytoplankton. In general, the light intensity to which the seaice and melt-pond communities were adapted $\left(I_{k}\right)$ and the light intensity at which photosynthesis is maximal $\left(I_{\mathrm{m}}\right)$ were similar to what they received $(I)$ at the time of sampling. In contrast, phytoplankton below the ice and in open waters, generally received less light than what they would need to perform optimally.

\subsection{Nutrient addition experiments}

For the first nutrient addition experiment, seawater was collected from the Chl $a$ max depth $(25 \mathrm{~m})$ at ice station 3 . It had low nitrate $(1.3 \mu \mathrm{mol} \mathrm{L}-1)$, phosphate $(0.1 \mu \mathrm{mol} \mathrm{L}-1)$ and silicate $\left(1.2 \mu \mathrm{mol} \mathrm{L}^{-1}\right)$ concentrations, and a Chl $a$ concentration of $1.6 \mu \mathrm{g} \mathrm{L}^{-1}$. Four days after the addition of $13 \mu \mathrm{mol} \mathrm{L}{ }^{-1} \mathrm{NO}_{3}^{-}, 0.8 \mu \mathrm{mol} \mathrm{L}^{-1} \mathrm{PO}_{4}^{3-}$ and $10 \mu \mathrm{mol} \mathrm{L}^{-1}$ $\mathrm{SiO}_{4}^{3-}$, to reach concentrations as below the mixed layer, NPP increased in the silica $(\mathrm{Si}+)$ treatment and in the positive control with all nutrients $(\mathrm{C}+$ ) (Fig. 5a). POC, PON and Chl $a$ only increased significantly when all nutrients were added (Fig. 6a). The increase in NPP corresponded to a carbon yield of $1.3 \mathrm{mg} \mathrm{C} \mathrm{L}^{-1} \mathrm{~d}^{-1}$, matching the POC increase of $1.6 \mathrm{mg} \mathrm{CL}^{-1} \mathrm{~d}^{-1}$ and the increase in PON $\left(0.15 \mathrm{mg} \mathrm{NL}^{-1} \mathrm{~d}^{-1}\right)$. The $\mathrm{C}: \mathrm{N}$ ratio in the $\mathrm{Si}+$ and $\mathrm{C}+$ treatments increased compared to the other treatments from 10 to 14 . Silicate uptake increased significantly in the $\mathrm{Si}+$ and $\mathrm{C}+$ treatments $(1.7$ and $\left.1.9 \mu \mathrm{mol} \mathrm{L}^{-1} \mathrm{~d}^{-1}\right)$ compared to the control with no nutrient addition $\left(0.2 \mu \mathrm{mol} \mathrm{L} \mathrm{L}^{-1} \mathrm{~d}^{-1} ;\right.$ Fig. 3b). This would correspond to a silicate yield of $0.07 \mathrm{mg} \mathrm{Si} \mathrm{L}^{-1} \mathrm{~d}^{-1}$. The organism responsible for the response was the chain forming diatom Chaetoceros socialis (Fig. 7a).

The sea ice sampled at station 8 was depleted in nutrients with very low nitrate $\left(0.2 \mu \mathrm{mol} \mathrm{L}^{-1}\right)$, phosphate $\left(0.1 \mu \mathrm{mol} \mathrm{L}{ }^{-1}\right)$ and silicate $\left(1 \mu \mathrm{mol} \mathrm{L}{ }^{-1}\right)$ concentrations. In this case, the addition of nutrients resulted in measurable nutrient uptake, but neither in a measurable increase in biomass nor in NPP (Figs. 5c, $d$ and $6 b$ ). Nitrate yield in the N+ treatment was $0.019 \mathrm{mg} \mathrm{N} \mathrm{L}^{-1} \mathrm{~d}^{-1}$, twice as much as the PON increase $\left(0.008 \mathrm{mg} \mathrm{N} \mathrm{L}^{-1} \mathrm{~d}^{-1}\right)$, indicating nitrate storage in the cells. The community composition of this sample was formed by typical sea-ice diatoms in a healthy state (with visible chloroplasts): Nitzschia sp., Pseudonitzschia sp., Fragilariopsis sp. and Entomoneis sp. (Fig. 7b). A few micrograzers (flagellates) were observed with the microscope and they might have contributed to nutrient uptake. 

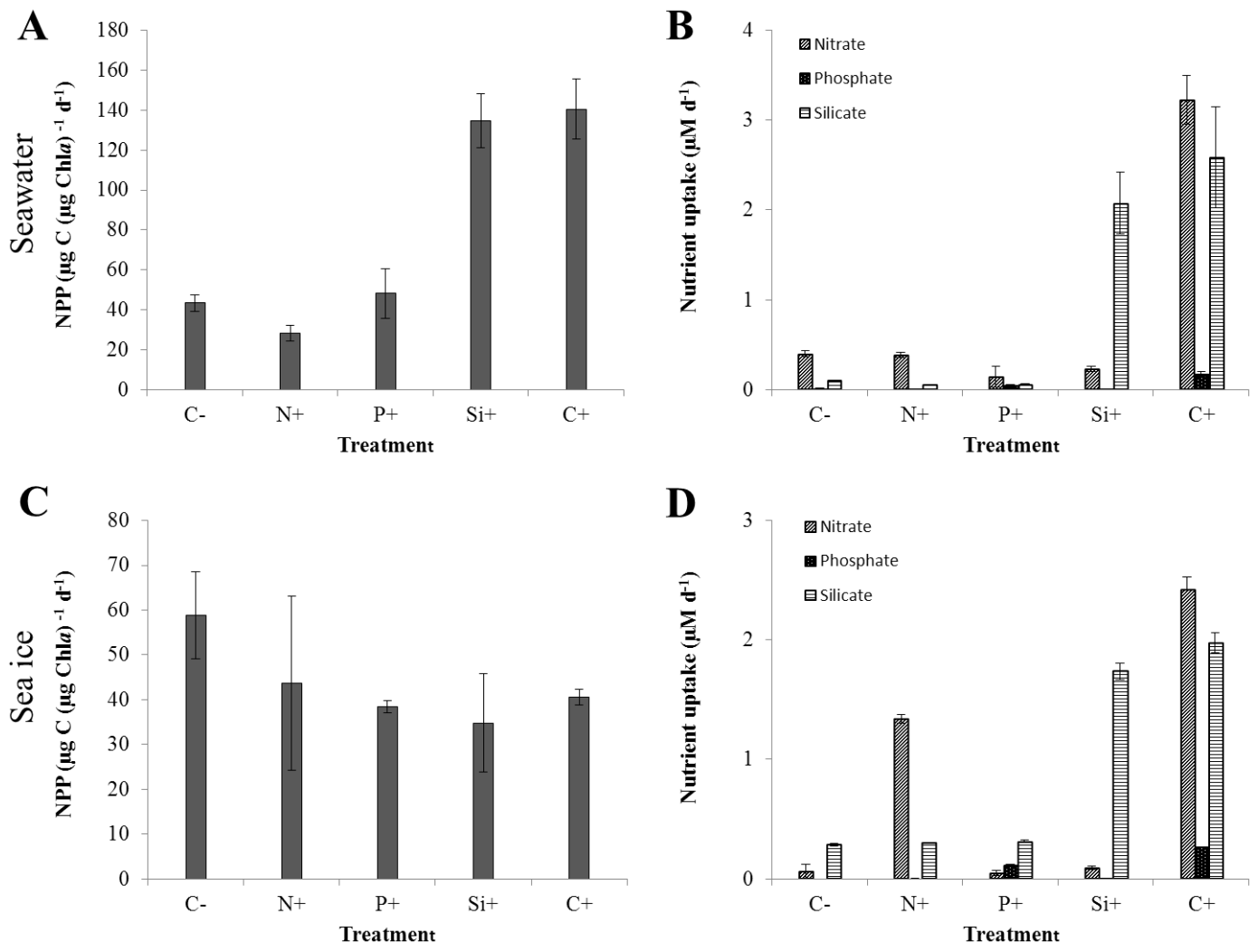

Figure 5. Nutrient addition experiments on seawater from ice station 3 (a, b) and sea ice from ice station 8 (c, d). (a) and (c) show the NPP rate of each treatment after $24 \mathrm{~h}$ of nutrient addition. (b) and (d) show the nutrient uptake in each treatment after nutrient addition. $\mathrm{C}$ is control, $\mathrm{N}^{+}$is nitrate, $\mathrm{P}^{+}$is phosphate, $\mathrm{Si}^{+}$is silicate, $\mathrm{C}^{+}$is all nutrients added.

\subsection{Net primary production in sea ice, melt ponds and water column}

Integrated over the depth of the euphotic zone, phytoplankton constituted most of the phototrophic biomass, expressed in Chl $a$ units, in all FYI stations (70-98\%), while sea-ice algae accounted for $68-86 \%$ of the biomass in the two MYI stations (Table 1). MYI contained almost 1 order of magnitude more Chl $a$ than FYI. Melt-pond water, excluding algal aggregates located at the bottom (Fernández-Méndez et al., 2014), contributed the least to integrated biomass (0.1$6 \%)$. The two melt ponds with the highest $\mathrm{Chl} a$ values $\left(\sim 0.3 \mathrm{mg} \mathrm{m}^{-2}\right)$ had the highest salinity (18 and 30 , respectively).

Net primary production of the water column was also integrated over the depth of the euphotic zone, which varied spatially. In open waters north of Svalbard and the Laptev Sea margin, the euphotic zone depth was $45 \mathrm{~m}$. In the partially ice-covered areas of the ice margin it ranged between 24 and $33 \mathrm{~m}$, and below thicker ice, north of $85^{\circ} \mathrm{N}$ in late September, it was between 7 and $15 \mathrm{~m}$ deep (Fig. 8a). Water column INPP measured from samples collected with the ship's CTD varied from 18 to $308 \mathrm{mg} \mathrm{C} \mathrm{m}^{-2} \mathrm{~d}^{-1}$ (average $95 \pm 78, n=11$ ) in ice-free waters of the central Arctic
Ocean in summer 2012, and from 0.1 to $232 \mathrm{mg} \mathrm{C} \mathrm{m}^{-2} \mathrm{~d}^{-1}$ (average $33 \pm 50, n=22$ ) in ice-covered waters (Fig. 2; Table S2). The large uncertainties in these values derive from averaging all stations, which are spatially and temporarily diverse. The highest INPP rates occurred at stations close to the shelves at the beginning of August, in a water mass that was not yet nutrient depleted (Fig. 4). The area adjacent to the Laptev Sea, which showed nitrate depletion, had INPP rates $\sim 100 \mathrm{mg} \mathrm{C} \mathrm{m}^{-2} \mathrm{~d}^{-1}$. The lowest INPP rates of $<1 \mathrm{mg} \mathrm{C} \mathrm{m}^{-2} \mathrm{~d}^{-1}$ were measured in nutrient-depleted icecovered waters north of $85^{\circ} \mathrm{N}$ in late September where PAR below the ice was $0.2-12 \mu$ mol photons $\mathrm{m}^{-2} \mathrm{~s}^{-1}$ (Fig. 4).

Total INPP rates including water below the ice, sea ice and melt ponds $\left(0.8-60 \mathrm{mg} \mathrm{C} \mathrm{m}^{-2} \mathrm{~d}^{-1}, n=8\right)$ also showed highest values along the ice edge and lowest in the northernmost stations, decreasing from late summer to early autumn. INPP in the water under the ice $\left(0.1-60 \mathrm{mg} \mathrm{C} \mathrm{m}^{-2} \mathrm{~d}^{-1}\right)$ contributed $63-99 \%$ to total INPP at ice margin stations (ice stations 1 to 6), while sea ice, in an advanced melting stage, contributed $0.1-33 \%\left(0.2-13 \mathrm{mg} \mathrm{C} \mathrm{m}^{-2} \mathrm{~d}^{-1}\right.$; Table S2 and Fig. 9). Meltpond-INPP ranged between 0.01 and $4 \mathrm{mg} \mathrm{C} \mathrm{m}^{-2} \mathrm{~d}^{-1}$, and their contribution to total INPP was highly variable $(0.05-$ $34 \%$ ). They contributed significantly to INPP at stations 3,7 and $8(24-34 \%)$. Sea-ice algae contributed significantly (50- 

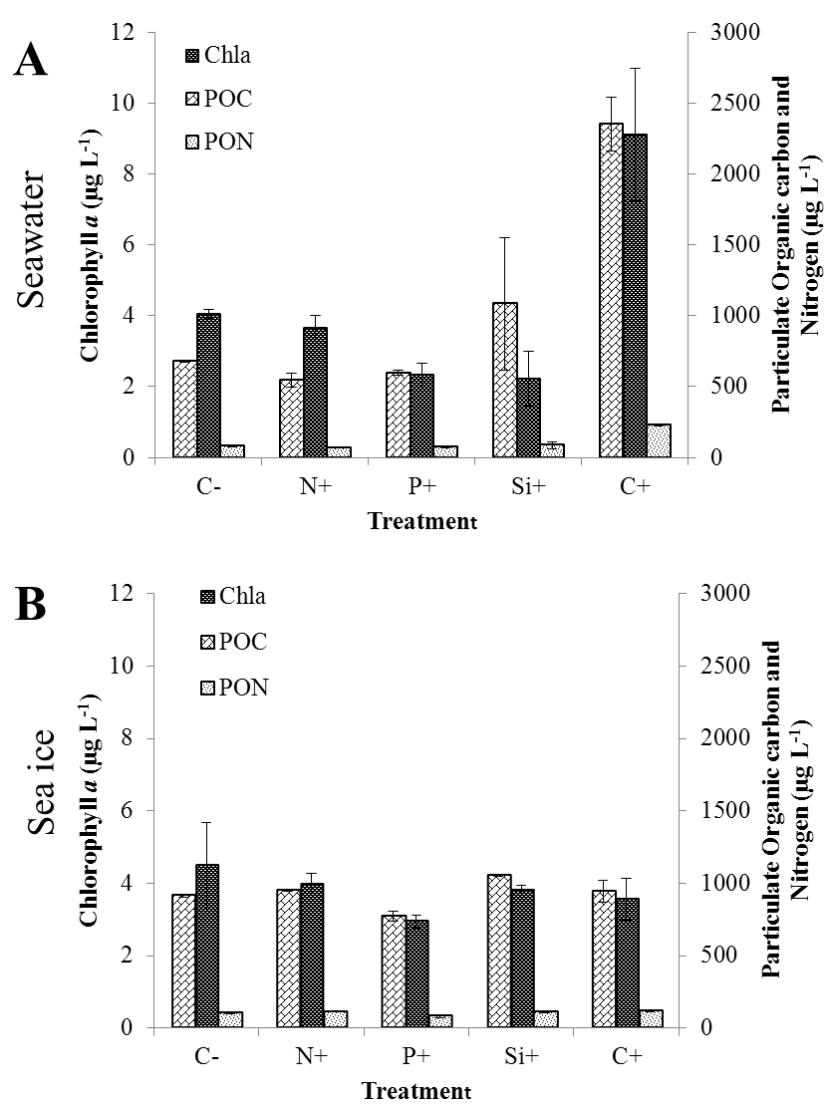

Figure 6. Biomass changes in nutrient addition experiments. (a) Nutrient addition experiment with seawater from the Chl $a$ max depth at station 3. (b) Nutrient addition experiment with sea ice from station 8. Duplicates of each treatment were incubated for 2 days after nutrient addition.

$62 \%)$ to total INPP at stations 7 and 8, despite their low total INPP rates (1.5 and $0.5 \mathrm{mg} \mathrm{C} \mathrm{m}^{-2} \mathrm{~d}^{-1}$, respectively), because the water column production was very low (Fig. 9).

\subsection{Annual new primary production}

The depth of the temperature minimum associated with haline convection during last winter had a mean of $55 \mathrm{~m}$ but ranged from 15 to $93 \mathrm{~m}$ depth (Fig. $8 \mathrm{~b}$ ). The depth of the winter haline convection sets the total amount of nutrients available at the surface for annual production. These nutrients will be used in the euphotic zone as the productive season evolves. Therefore, in situ production is integrated until the euphotic zone depth while annual production based on nutrient uptake is integrated until the winter haline convection depth. Stations north of $85^{\circ} \mathrm{N}$ covered by MYI showed the deepest values. According to the nutrient profiles at the end of the productive season, the total inorganic nitrogen $\left(\mathrm{NO}_{3}^{-}+\mathrm{NO}_{2}^{-}\right)$consumption was $119 \pm 46 \mathrm{mmol} \mathrm{m}^{-2}$. Using the Redfield ratio $(106 \mathrm{C}: 16 \mathrm{~N})$, we estimated the carbon used up for annual new production from nitrogen con- sumption to be between 0.6 and $17 \mathrm{~g} \mathrm{C} \mathrm{m}^{-2} \mathrm{yr}^{-1}$ (average: $9.4 \pm 3.6 \mathrm{~g} \mathrm{C} \mathrm{m}^{-2} \mathrm{yr}^{-1} ;$ Fig. 10). Assuming a productive season of 120 days (Gradinger, 2009), the average INPP rate for the Eurasian Basin was $78 \pm 30 \mathrm{mg} \mathrm{C} \mathrm{m}^{-2} \mathrm{~d}^{-1}$, which is in the upper range of our in situ measurements in late summer including sea-ice INPP. This value decreases if we increase the length of the productive period. Indeed, due to earlier seaice retreat it might be that the productive season in the central Arctic Ocean was longer in 2012. Annual new production is homogenously distributed through the Eurasian Basin. Only the most northern stations show higher annual INPP (13$17 \mathrm{~g} \mathrm{C} \mathrm{m}^{-2} \mathrm{yr}^{-1}$ ), corresponding to the shallowest euphotic zone as well as the deepest winter haline convection depth $(70-80 \mathrm{~m})$ causing a higher nutrient availability and drawdown.

New production based on phosphate drawdown using Redfield gives a similar range $\left(1-16 \mathrm{~g} \mathrm{C} \mathrm{m}^{-2} \mathrm{yr}^{-1}\right)$. Using silicate draw-down in the ratio typical for diatoms $(7 \mathrm{C}: \mathrm{Si})$ gives an annual carbon uptake range of $0.01-7 \mathrm{~g} \mathrm{C} \mathrm{m}^{-2} \mathrm{yr}^{-1}$, meaning that around $10-50 \%$ of the annual carbon uptake based on nitrate was performed by this group of phytoplankton (Fig. 10). Sea-ice algae sampled in August-September showed an $\mathrm{C}: \mathrm{Si}$ ratio average of 9 . Using this higher $\mathrm{C}: \mathrm{Si}$ ratio, and assuming that sea-ice algae are the main consumer of silicate during the growth season, this would yield annual carbon uptake values 20-30\% higher. However, sea-ice algae may have a $\mathrm{C}: \mathrm{Si}$ ratio closer to Redfield during the growing season when new production occurs. The new production value would decrease if nutrient uptake by heterotrophs were taken into account, and increase if nutrient replenishment by physical advection or biological remineralization would take place. Unfortunately we could not assess these processes during the mission.

\subsection{Arctic primary production model: CAOPP estimates}

Average PI curves and Chl $a$ profiles were calculated for each environment from summer 2012 measurements. They were used to calculate NPP as a function of available PAR for the Eurasian Basin of the Arctic Ocean $\left(78-90^{\circ} \mathrm{N}, 135^{\circ} \mathrm{E}-\right.$ $45^{\circ} \mathrm{W}$ ) using the CAOPP model. We present here the results calculated with average parameters, and the minimum and maximum values are available in Table 4 . The average total INPP for the Eurasian Basin was $54 \mathrm{mg} \mathrm{C} \mathrm{m}^{-2} \mathrm{~d}^{-1}$ in August and $34 \mathrm{mg} \mathrm{C} \mathrm{m}^{-2} \mathrm{~d}^{-1}$ in September 2012. We observed a decrease in total INPP from August to September, in parallel with a decrease in incoming irradiance (Fig. 11). On average at a basin scale, in late summer-early autumn, sea-ice algae contributed $6 \%$ to total INPP in the Eurasian Basin, while NPP in melt ponds was almost negligible (1\%) (Fig. 12). Algal aggregates trapped in melt ponds were not taken into account due to their patchiness and difficulty to upscale their contribution to NPP (Fernández-Méndez et al., 2014). Ice- 


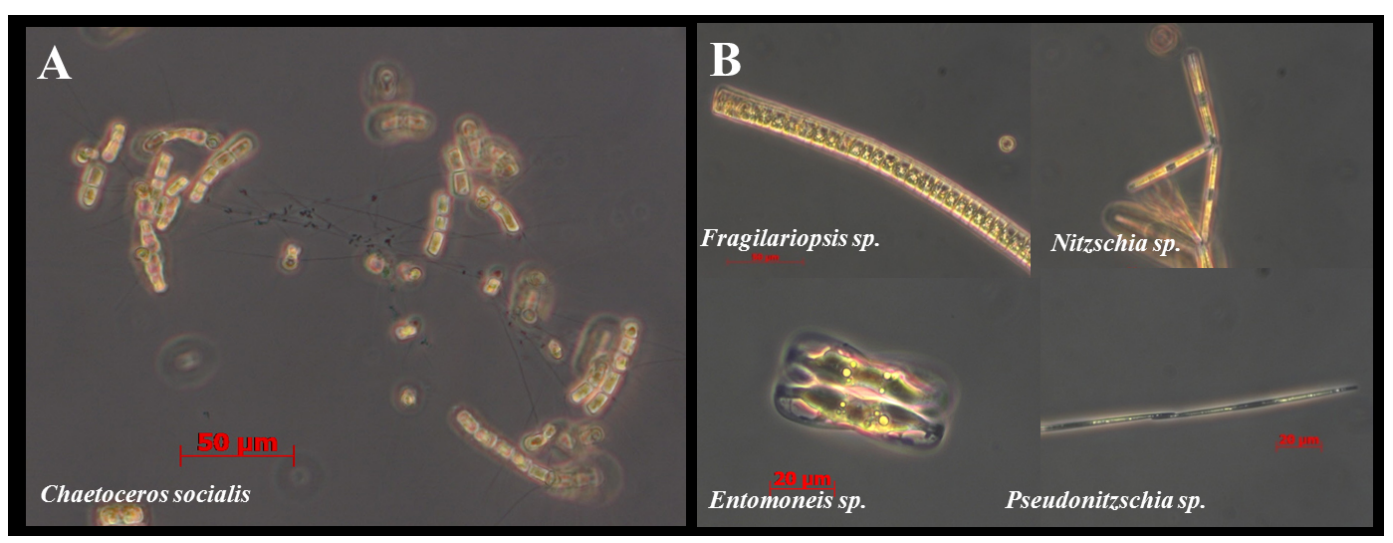

Figure 7. Microscopy images of the community composition of the two nutrient experiments: (a) seawater phytoplankton and (b) sea-ice algae.

A Euphotic zone depth.summer $2012(\mathrm{~m})$

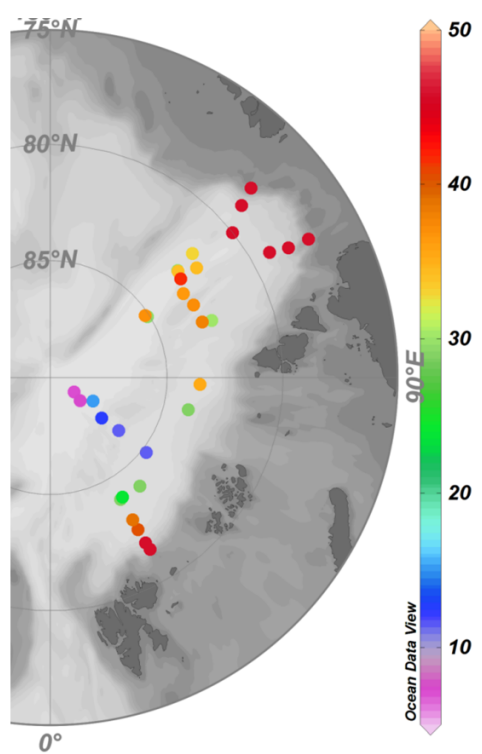

B Winter mixed layer depth (m)

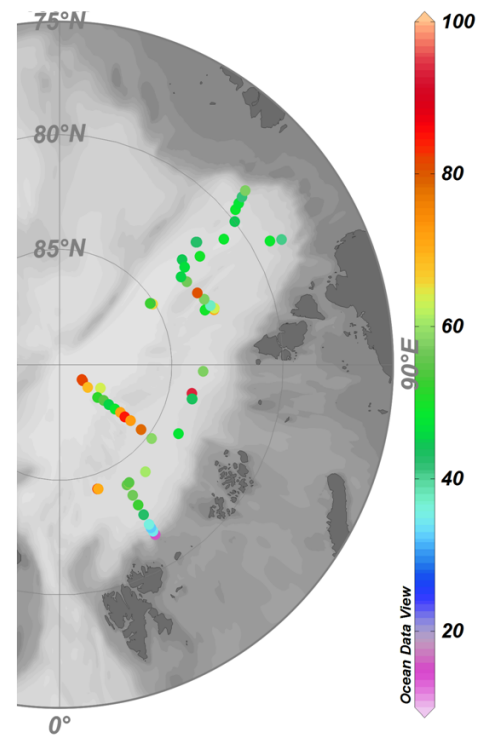

Figure 8. Euphotic zone depth (1\% PAR) weighted average (a), and winter mixed layer depth (b) estimated from summer temperature profiles. Average and standard deviations: euphotic zone depth $34 \pm 6 \mathrm{~m}$; winter mixed layer depth $54 \pm 15 \mathrm{~m}$.

covered waters contributed significantly less $(36 \%)$ to total NPP per month than open water $(57 \%)$ north of $78^{\circ} \mathrm{N}$.

When running the CAOPP model with the sea-ice conditions of September 1982 (Fig. 13) (mainly $>2 \mathrm{~m}$ thick MYI), the INPP in the Eurasian Basin was half the NPP in September 2012 (Table 5) assuming that the nutrient concentrations in surface waters and the percentage of melt pond cover were the same in 1982 as in 2012, since no data were available for 1982. In general, the reduction of both MYI and FYI from 1982 to 2012 has led to a $\sim 20 \%$ decrease in the contribution of sea-ice production to total INPP and an increase in water column contribution to total INPP. The fraction of MYI has been reduced the most in the Laptev Sea, where the total INPP has increased $53 \%$ according to our model. In a po- tential scenario in which the Arctic would be completely icefree in September (2050) and nutrients and the mixed layer depth would remain as in 2012, INPP could increase $60 \%$ on average in the Eurasian Basin north of $78^{\circ} \mathrm{N}$ with the biggest increases occurring in the Barents and Greenland sectors due to the reduction in MYI fraction and the consequent increase in euphotic zone depth from 6-25 $\mathrm{m}$ to $\sim 50 \mathrm{~m}$ (Table 5). 
Table 4. Integrated net primary production in the central Arctic at different times and spatial scales. The number of daily measurements is given in Table 2. The contribution by sub-ice-algal aggregates is not included in any of the values presented in this table.

\begin{tabular}{|c|c|c|c|c|c|c|}
\hline \multirow[b]{5}{*}{ INPP in the Eurasian Basin } & \multicolumn{6}{|c|}{ Integrated net primary production (INPP) } \\
\hline & \multirow{4}{*}{$\begin{array}{l}\text { Daily } \\
\text { In situ } \\
\text { Mean } \pm \mathrm{SD} \\
\mathrm{mgC} \mathrm{m}^{-2} \mathrm{~d}^{-1}\end{array}$} & \multicolumn{4}{|c|}{ Monthly } & \multirow{4}{*}{$\begin{array}{l}\text { Annual } \\
2012 \\
\text { Mean } \pm \text { SD }\end{array}$} \\
\hline & & & August & & ptember & \\
\hline & & \multicolumn{4}{|c|}{ Mean (Min-Max) } & \\
\hline & & \multicolumn{3}{|c|}{$\mathrm{mgC} \mathrm{m}{ }^{-2} \mathrm{~d}^{-1}$} & $\mathrm{gC} \mathrm{m}^{-2} \mathrm{yr}^{-1}$ & \\
\hline Total & $24 \pm 19$ & 54 & $(21-180)$ & 34 & $(21-65)$ & $9.4 \pm 3.6$ \\
\hline Sea ice & $2.2 \pm 4.1$ & 5.8 & $(0.06-42)$ & 2.6 & $(0.02-20)$ & \\
\hline Melt ponds & $0.9 \pm 1.3$ & 0.5 & $(0.2-1.7)$ & 0.7 & $(0.06-3)$ & \\
\hline Water under the ice & $20 \pm 20$ & 31 & $(4.5-116)$ & 12 & $(3-50)$ & \\
\hline \multirow[t]{2}{*}{ Open water } & $84 \pm 38$ & 97 & $(62-115)$ & 56 & $(43-50)$ & \\
\hline & Mean Area & \multicolumn{4}{|c|}{ Sum } & Sum \\
\hline INPP in the central $\operatorname{Arctic}\left(78^{\circ} \mathrm{N}\right)$ & $\operatorname{TgCd} d^{-1}$ & \multicolumn{4}{|c|}{ 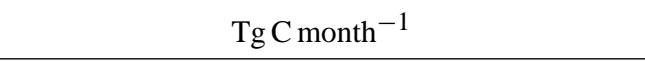 } & $\mathrm{TgC} \mathrm{yr}^{-1}$ \\
\hline Total & $0.09 \pm 0.07$ & 5.7 & $(1.7-24)$ & 3.4 & $(1.78-8.45)$ & 36 \\
\hline INPP in the Eurasian Basin & $\operatorname{TgCd}^{-1}$ & \multicolumn{4}{|c|}{$\operatorname{TgC~\text {month}^{-1}}$} & $\operatorname{TgC~} \mathrm{yr}^{-1}$ \\
\hline Total & $0.04 \pm 0.03$ & 3.1 & $(1.2-10)$ & 1.9 & $(1.1-3.6)$ & $7.4 \pm 6.7$ \\
\hline Sea ice & $0.004 \pm 0.007$ & 0.2 & $(0.002-1.7)$ & 0.08 & $(0.0008-0.6)$ & \\
\hline FYI & $0.004 \pm 0.009$ & 0.05 & $(0.002-0.4)$ & 0.008 & $(0.0004-0.06)$ & \\
\hline MYI & $0.002 \pm 0.001$ & 0.2 & $(0.0003-1.2)$ & 0.07 & $(0.0002-0.5)$ & \\
\hline Melt ponds & $0.002 \pm 0.002$ & 0.02 & $(0.007-0.07)$ & 0.02 & $(0.002-0.09)$ & \\
\hline Water under the ice & $0.04 \pm 0.04$ & 1.3 & $(0.2-6.8)$ & 0.4 & $(0.1-1.6)$ & \\
\hline Open water & $0.16 \pm 0.071$ & 1.5 & $(1-1.8)$ & 1.4 & $(1-1.3)$ & \\
\hline
\end{tabular}

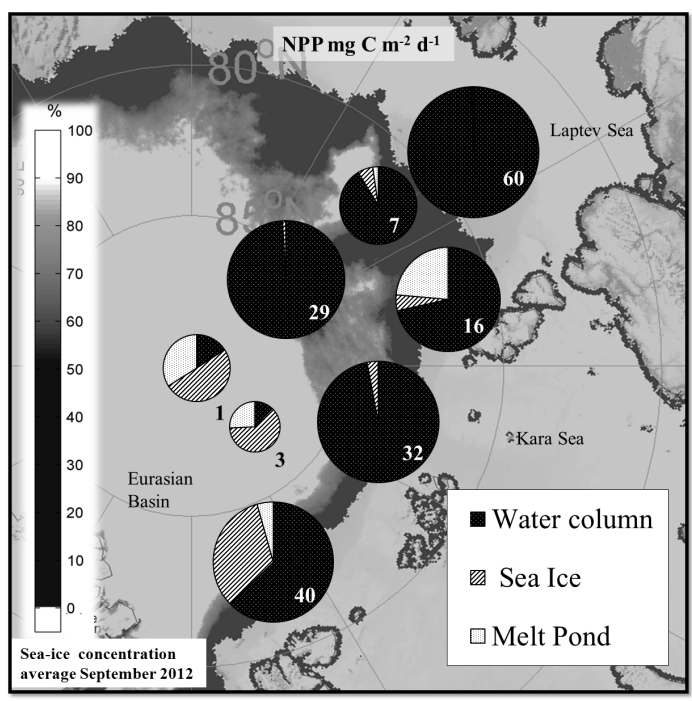

Figure 9. Depth-integrated net primary productivity (INPP) and the contribution of sea ice, melt ponds and water at eight ice stations in the Eurasian Basin during summer 2012. The size of the pie chart represents the magnitude of INPP in $\mathrm{mg} \mathrm{C} \mathrm{m}^{-2} \mathrm{~d}^{-1}$. The values are depicted next to each pie chart.

\section{Discussion}

\subsection{Importance of sea-ice productivity in the central Arctic Ocean}

The role of sea-ice algae varies regionally and seasonally in the Arctic Ocean (Dupont, 2012; Legendre et al., 1992). In agreement with previous data by Gosselin et al. (1997) for August 1994, sea-ice algae contributed up to $60 \%$ to total NPP in those parts of the central Arctic Ocean covered by MYI at the end of the productive season in 2012 . However, our contribution estimate is conservative, since the sub-ice-algal aggregates formed by Melosira arctica that we observed at all stations can contribute up to $90 \%$ of total NPP at a local scale (Fernández-Méndez et al., 2014). Due to their patchy distribution and the difficulties in upscaling sub-ice-algal aggregates contribution to NPP (Katlein et al., 2014a), they were not included in the sea-ice NPP estimates presented in this study, although they were observed at all stations.

In areas covered by FYI, sea-ice productivity contributed only $1-30 \%$ to total INPP (Fig. 12). MYI has different physical properties than FYI (Lange et al., 2015; Spindler, 1994) and generally hosts a higher algal biomass concentration (Werner et al., 2007). In total, MYI and FYI together fixed 0.31 Tg C during August and September 2012, without tak- 
Table 5. Comparison of three runs of the CAOPP model using the photosynthetic parameters measured in situ in summer 2012. Sea-ice extent, multiyear ice fraction, incoming irradiance and mean INPP in Tg C month ${ }^{-1}$ are presented for the month of September in 1982,2012 and 2050. Since the purpose is a magnitude comparison between different scenarios in the different sectors of the Eurasian Basin (depicted in Fig. 13), only the mean is shown. Min and Max values would deviate from the mean as presented in Table 4 for 2012.

\begin{tabular}{|c|c|c|c|c|}
\hline & \multicolumn{4}{|c|}{ CAOPP results for September north of $78^{\circ} \mathrm{N}$} \\
\hline & $\begin{array}{l}\text { September ice } \\
\text { extent } \\
\text { mean } \\
\text { mio. } \mathrm{km}^{-2}\end{array}$ & $\begin{array}{c}\text { MYI } \\
\text { fraction } \\
\text { mean } \\
\%\end{array}$ & $\begin{array}{l}\text { Incoming } \\
\text { irradiance } \\
\text { mean (Min-Max) } \\
\mu \text { mol photons } \mathrm{m}^{-2} \mathrm{~s}^{-1}\end{array}$ & 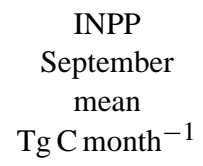 \\
\hline & \multicolumn{4}{|c|}{$1982\left(7.17\right.$ million $\left.\mathrm{km}^{2}\right)$} \\
\hline Eurasian Basin $\left(78-90^{\circ} \mathrm{N}, 45^{\circ} \mathrm{W}-135^{\circ} \mathrm{E}\right)$ & 1.78 & 71 & $59(28-122)$ & 0.93 \\
\hline Laptev $\left(78-90^{\circ} \mathrm{N}, 90-135^{\circ} \mathrm{E}\right)$ & 0.53 & 92 & $54(28-84)$ & 0.26 \\
\hline Kara $\left(78-90^{\circ} \mathrm{N}, 45-90^{\circ} \mathrm{E}\right)$ & 0.50 & 85 & $59(31-75)$ & 0.27 \\
\hline Barents $\left(78-90^{\circ} \mathrm{N}, 0-45^{\circ} \mathrm{E}\right)$ & 0.44 & 88 & $64(30-104)$ & 0.26 \\
\hline \multirow[t]{2}{*}{ Greenland $\left(78-90^{\circ} \mathrm{N}, 45^{\circ} \mathrm{W}-0^{\circ} \mathrm{E}\right)$} & 0.31 & 82 & $63(29-122)$ & 0.13 \\
\hline & \multicolumn{4}{|c|}{$2012\left(3.42\right.$ million $\left.\mathrm{km}^{2}\right)$} \\
\hline Eurasian Basin $\left(78-90^{\circ} \mathrm{N}, 45^{\circ} \mathrm{W}-135^{\circ} \mathrm{E}\right)$ & 1.01 & 51 & $45(23-102)$ & 1.88 \\
\hline Laptev $\left(78-90^{\circ} \mathrm{N}, 90-135^{\circ} \mathrm{E}\right)$ & 0.29 & 12 & $47(24-84)$ & 0.63 \\
\hline Kara $\left(78-90^{\circ} \mathrm{N}, 45-90^{\circ} \mathrm{E}\right)$ & 0.16 & 30 & $42(25-76)$ & 0.66 \\
\hline Barents $\left(78-90^{\circ} \mathrm{N}, 0-45^{\circ} \mathrm{E}\right)$ & 0.25 & 50 & $42(25-69)$ & 0.46 \\
\hline \multirow[t]{2}{*}{ Greenland $\left(78-90^{\circ} \mathrm{N}, 45^{\circ} \mathrm{W}-0^{\circ} \mathrm{E}\right)$} & 0.30 & 77 & $52(24-102)$ & 0h.13 \\
\hline & \multicolumn{4}{|c|}{2050 (No ice) Wang and Overland (2012) } \\
\hline Eurasian Basin $\left(78-90^{\circ} \mathrm{N}, 45^{\circ} \mathrm{W}-135^{\circ} \mathrm{E}\right)$ & 0 & 0 & $45(23-102)$ & 2.91 \\
\hline Laptev $\left(78-90^{\circ} \mathrm{N}, 90-135^{\circ} \mathrm{E}\right)$ & 0 & 0 & $47(24-84)$ & 0.87 \\
\hline Kara $\left(78-90^{\circ} \mathrm{N}, 45-90^{\circ} \mathrm{E}\right)$ & 0 & 0 & $42(25-76)$ & 0.81 \\
\hline Barents $\left(78-90^{\circ} \mathrm{N}, 0-45^{\circ} \mathrm{E}\right)$ & 0 & 0 & $42(25-69)$ & 0.72 \\
\hline Greenland $\left(78-90^{\circ} \mathrm{N}, 45^{\circ} \mathrm{W}-0^{\circ} \mathrm{E}\right)$ & 0 & 0 & $52(24-102)$ & 0.51 \\
\hline
\end{tabular}

ing the patchily distributed under-ice and melt-pond-algal aggregates into account (Fernández-Méndez et al., 2014). This corresponds to $6 \%$ of the total carbon fixed in the Eurasian Basin north of $78^{\circ} \mathrm{N}$ in summer. This estimate is in agreement with annual estimates from a biophysical model where sea-ice primary production contributes $7.5 \%$ to total annual PP for the whole Arctic (Dupont, 2012).

However, our sea-ice INPP measurements (0.1$13 \mathrm{mg} \mathrm{C} \mathrm{m}^{-2} \mathrm{~d}^{-1}$ ) in August and September fell in the lower end of the range of previously reported values from 2 decades earlier in the same area $\left(0.5-310 \mathrm{mg} \mathrm{C} \mathrm{m}^{-2} \mathrm{~d}^{-1}\right.$, Gosselin et al., 1997). This difference could be due to interannual variability, or to the loss of MYI, highlighting the need for more NPP data from the central Arctic Ocean. The higher end of the range in that study (AOS expedition, 1994) refers to sub-ice-algal communities formed by sub-ice diatoms like Melosira arctica. This diatom was also found to comprise much of the total-algal biomass during our expedition at station 7 , showing an INPP of $13-40 \mathrm{mg} \mathrm{C} \mathrm{m}^{-2} \mathrm{~d}^{-1}$, similar to the AOS expedition estimates (Fernández-Méndez et al., 2014), and even more to total export flux. The rapid sea-ice melt in July/August 2012 led to major sinking of fresh-algal biomass to the seafloor of the Arctic basins
(Boetius et al., 2013). If we assume that the sinking algae had previously contributed to NPP at the surface, and that they occurred throughout the entire Eurasian Basin north of $78^{\circ} \mathrm{N}\left(1.8 \times 10^{12} \mathrm{~m}^{2}\right)$, the average $9 \mathrm{~g} \mathrm{C} \mathrm{m}^{-2}$ (range: $1-156 \mathrm{~g} \mathrm{C} \mathrm{m}^{-2}$ ) of sub-ice algae found deposited at the seafloor would have contributed an additional $16 \mathrm{TgC}$ to INPP. From the nitrate annual drawdown, we calculated a total carbon uptake of $17 \pm 7 \mathrm{Tg} \mathrm{Cyr}^{-1}$ in the Eurasian Basin north of $78^{\circ} \mathrm{N}$. However, this calculation does not take into account lateral scavenging of nutrients by sub-ice algae such as Melosira arctica. Algal filaments hanging from the sea ice are transported along the Transpolar drift, from the Siberian shelves where ice is formed, to the central Arctic Ocean. Hence, they may have a better access to nutrients than phytoplankton. This lateral scavenging of nutrients by the sub-ice algae should be added to the nutrient drawdown calculated from vertical profiles. Accordingly, when adding the nutrients taken up by the sub-ice algae, the total new production could be $17+16=33 \pm 7 \mathrm{Tg} \mathrm{C} \mathrm{yr}^{-1}$ in the deep basins of the Eurasian Basin. The overall contribution of sea-ice productivity would be $50 \%$. When including sub-ice algal aggregations such as Melosira arctica filaments, the average total production of $33 \mathrm{TgC}^{-1}$ in the Eurasian 


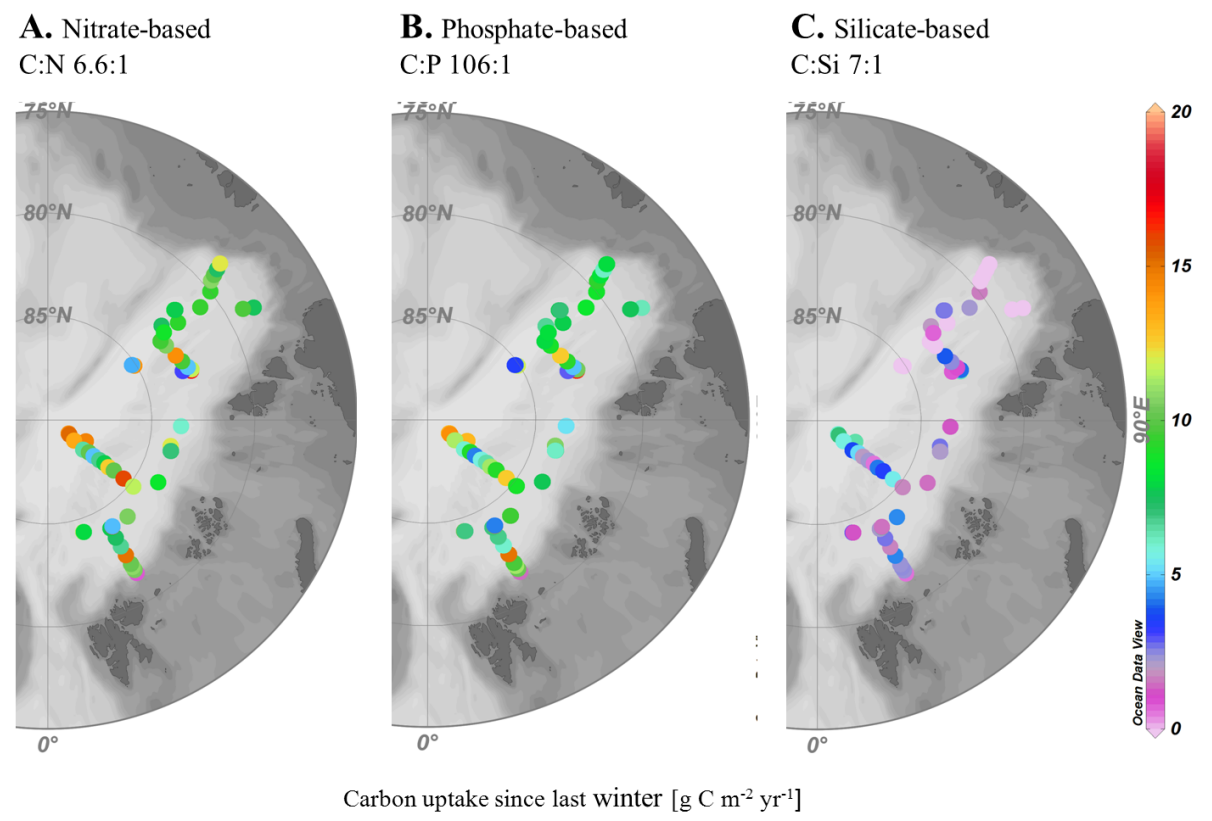

Figure 10. New production in the Eurasian Basin during 2012. Carbon uptake since last winter estimated from nitrate (a), phosphate (b) and silicate (c) drawdown in the mixed layer. Redfield ratio $\mathrm{C}: \mathrm{N}: \mathrm{Si}: \mathrm{P}$ of 106:16:15:1 was used to convert nutrient uptake into annual new production.

Basin of the central Arctic Ocean is higher than previously estimated (22 $\mathrm{Tg} \mathrm{C} \mathrm{yr}^{-1}$, Codispoti et al., 2013). Therefore, studies that do not include sea-ice productivity and sub-icealgal aggregations may substantially underestimate annual NPP in the central basins and other ice-covered regions (Matrai and Apollonio, 2013).

Melt ponds contributed up to $4 \%$ to total INPP, which is in the range of previously reported estimates $(<1$ to $10 \%$, Arrigo, 2014; Lee et al., 2012). Some melt ponds also contain significant accumulations of algal biomass (FernándezMéndez et al., 2014), and hence might also become more important for total Arctic PP as their coverage continues to increase (Lee et al., 2011; Rösel and Kaleschke, 2012). Some of the sea-ice algae trapped in melt ponds can rapidly adapt to the changing conditions, as we observed in their high Chl $a$ normalized maximum photosynthetic rates compared to all other environments. Sea-ice algae are low light adapted (Table 2; Cota, 1985) and show lower photoinhibition in late summer (Michel et al., 1988; Mundy et al., 2011). However, in June-July when they receive $90 \%$ of the annual light flux (Arndt and Nicolaus, 2014), they have their peak in production and thus seem to adapt to higher light conditions. This would have already been exported to the deep sea when we did our sampling in August-September.

An important question concerns the ability of sea-ice algae to deal with nutrient limitations. Integrated over the ice thickness and melt-pond depth, nutrient concentrations were significantly lower than in the water column. $\mathrm{N}: \mathrm{P}$ molar ratios in sea ice were in general below Redfield (16:1) indicating prior production by ice algae limited by nitrate (Maestrini et al., 1986; Smith et al., 1997). Melt-pond nutrient ratios were very variable (Table 3 ) highlighting the high spatial heterogeneity of this environment. Very high $\mathrm{N}: \mathrm{Si}$ ratios $(>3)$ at some stations point towards silicate limitation as well. Our nutrient addition experiment (Fig. 3d) suggests that sea-ice algal communities can take up nutrients without increasing their biomass, which is in agreement with previous findings that sea-ice diatoms can store nutrients in their cytoplasma (Kamp et al., 2011; Needoba and Harrison, 2004). This may be an important physiological trait of sea-ice algae to cope with the oligotrophic conditions of the deep central Arctic Ocean.

\subsection{Light and nutrients as limiting factors}

Seasonal light availability in the central Arctic Ocean limits photosynthesis (Leu et al., 2011; Wassmann and Reigstad, 2011). Our in situ measurements and upscaling results using the CAOPP model clearly show the strong effect of sea-ice cover and season on NPP (Figs. 4 and 5). The comparison between ice-free and ice-covered waters of the Eurasian Basin reveals the indirect effect of sea ice through light attenuation, limiting phytoplankton productivity in ice-covered waters. This is noticeable at the end of the productive season (midSeptember), north of $87^{\circ} \mathrm{N}$, below MYI, where the euphotic zone is reduced to the upper 7-15 m (Fig. 8a). Hence, years with an extensive ice melt as in 2012 host twice as much NPP in the Eurasian Basin as years with typical (previous to the current trend of sea-ice extent decrease) sea-ice cover such as 1982 (Table 5). 

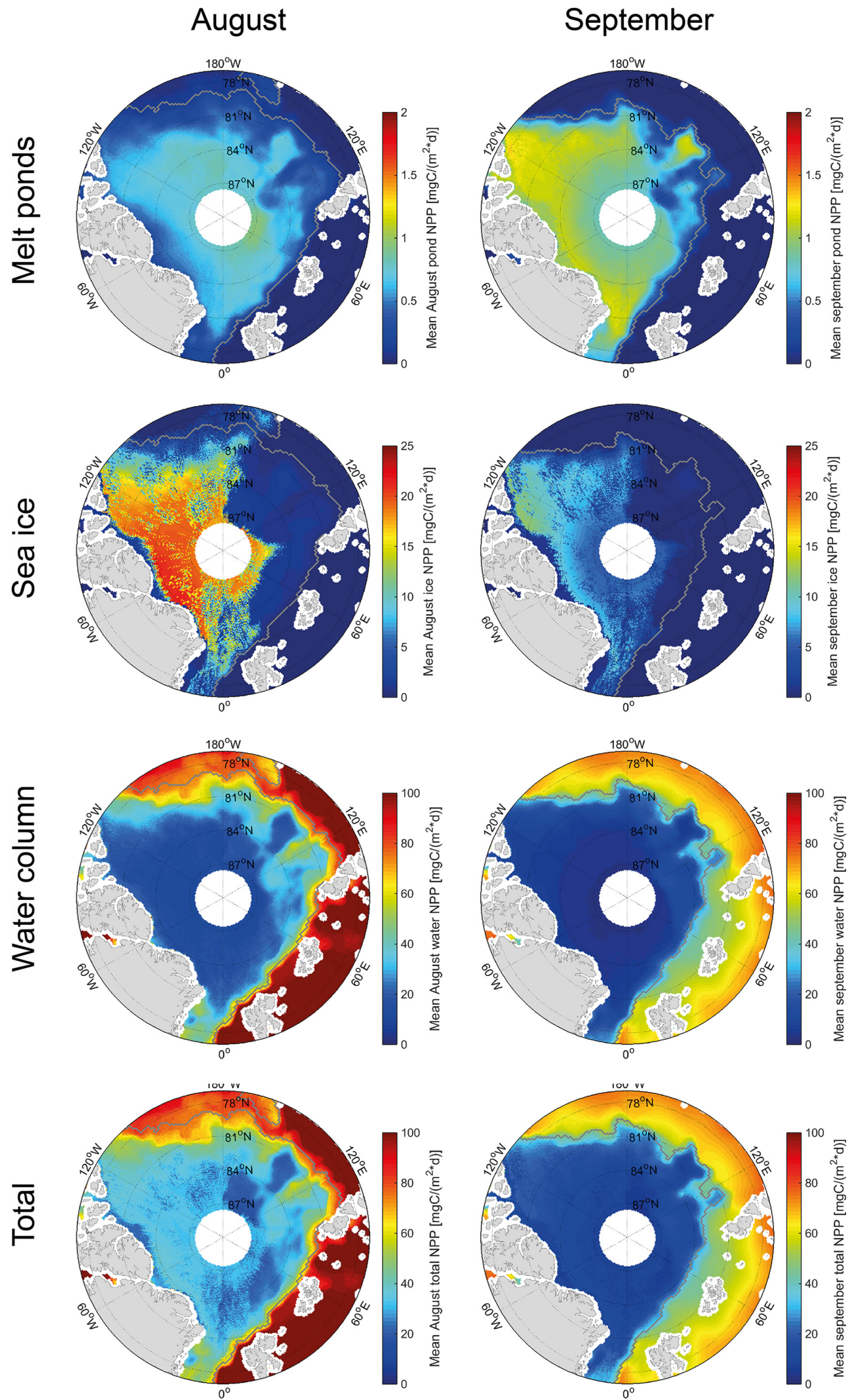

Figure 11. Total mean INPP in $\mathrm{mg} \mathrm{C} \mathrm{m}^{-2} \mathrm{~d}^{-1}$ and in each environment: melt ponds, sea ice and water in the central Arctic Ocean during August and September 2012 as modelled with the CAOPP model. The grey line depicts the average sea ice extent for each month. Note the different scales in the different panels. 


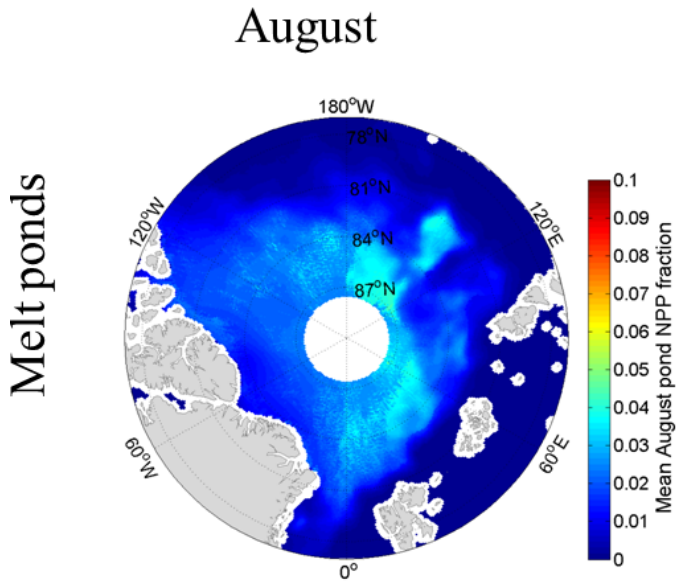

\section{September}
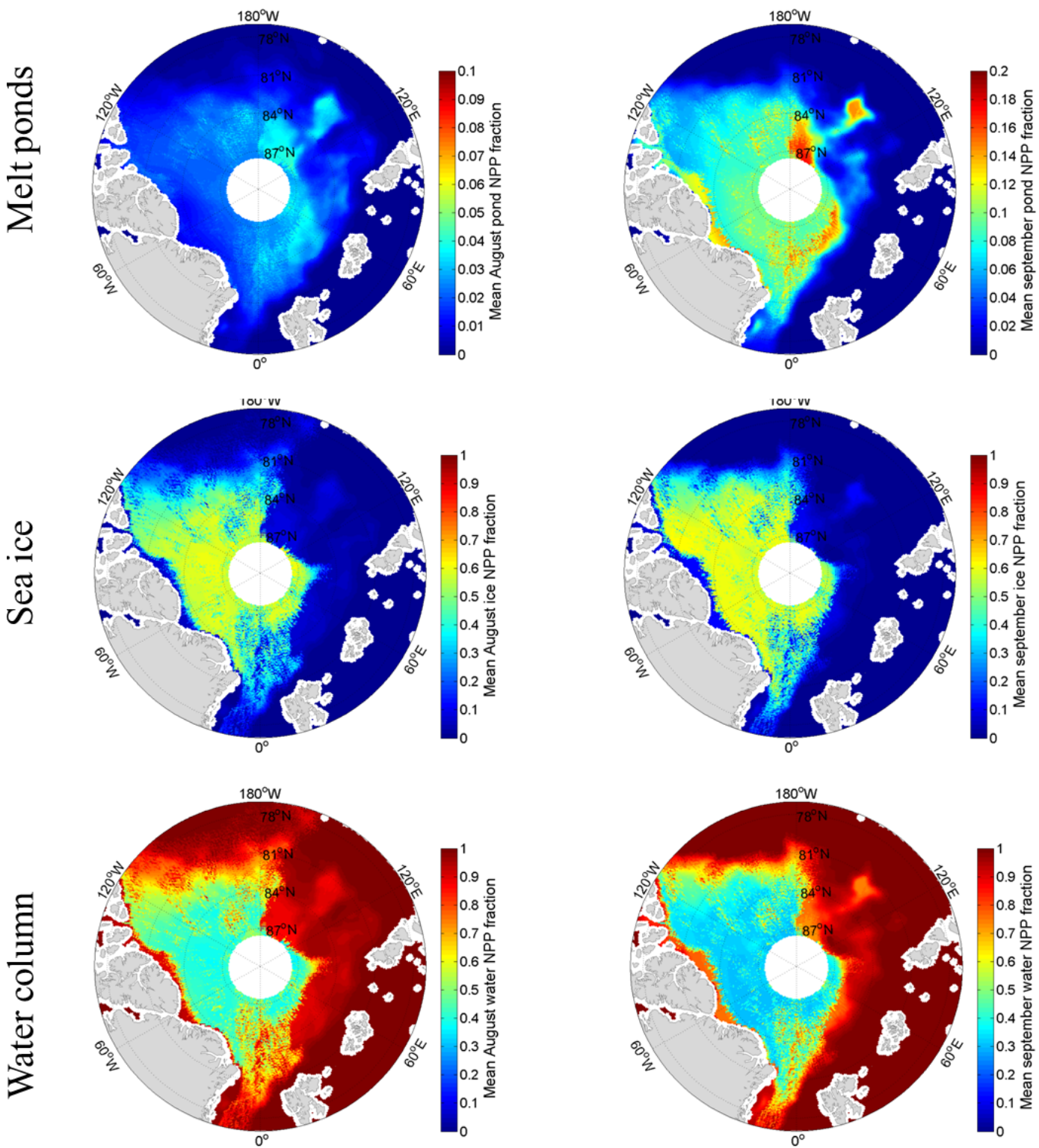

Figure 12. Fraction contribution of NPP in each environment (melt ponds, sea ice and water column) to total NPP in the central Arctic during August and September 2012 according to the upscaling performed using the CAOPP model. The assumptions for key factors governing NPP are explained in the "Methods" section. Note the different scales of the panels.

Sea-ice algae are adapted to low light but can profit from increased light availability in thin ice in late summer $\left(I_{k}\right.$ range from sea ice and melt ponds 17$290 \mu \mathrm{mol}$ photons $\mathrm{m}^{-2} \mathrm{~s}^{-1}$; Table 2). However, lack of snow covering the ice at the beginning of the growth season can also be detrimental for the sea-ice community due to photoinhibition and ice bottom ablation (Juhl and Krembs, 2010; Lund-Hansen et al., 2014; Mundy et al., 2011). In our study, evidence for photoinhibition was mainly recorded in August on sea-ice algae trapped at the ice surface of melt ponds where the irradiance was maximal (up to $279 \mu$ mol photons $\mathrm{m}^{-2} \mathrm{~s}^{-1}$; Fig. 2; Table 3). However, the highest irradiance fluxes in 2012 occurred in June (Arndt and Nicolaus, 2014), so the potential for photoinhibition was higher in the earlier summer months, especially if no snow was covering the ice. Phytoplankton sampled at $2-5 \mathrm{~m}$ depth on the contrary showed almost no photoinhibition under irradiances up to $420 \mu \mathrm{mol}$ photons $\mathrm{m}^{-2} \mathrm{~s}^{-1}$, allowing them to potentially benefit even more from an increase in irradiance reaching the water column. 


$$
\begin{aligned}
& \text { A NPP with } 1982 \text { ice cover } \\
& \text { Previous to sea-ice decline }
\end{aligned}
$$

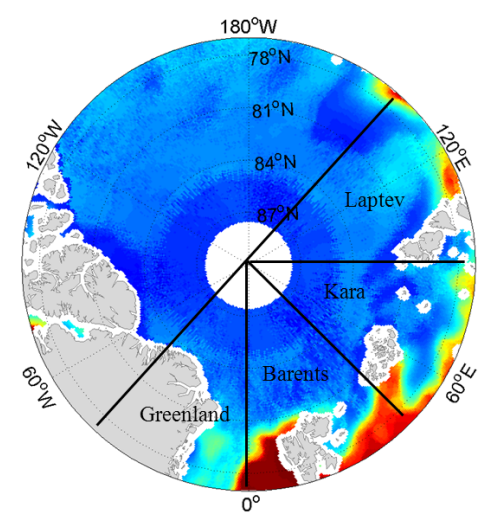

B NPP with no ice cover Predicted to occur in 2050

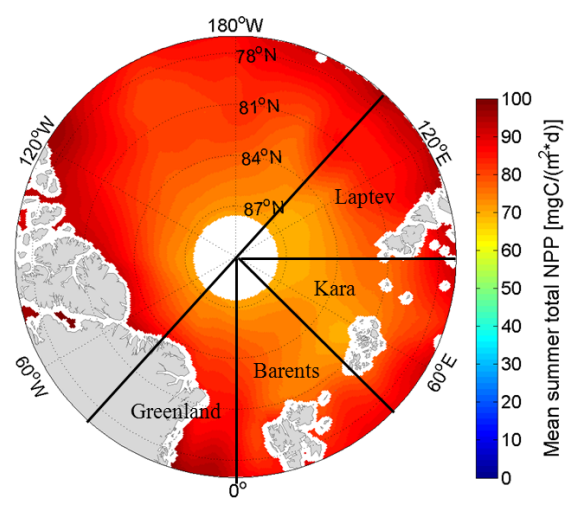

Figure 13. September mean total INPP for two runs of the CAOPP model under contrasting sea-ice conditions: (a) sea-ice cover and incoming irradiance as in 1982, (b) no-ice cover as predicted for 2050. Nutrient concentrations and photosynthetic parameters as in September 2012.

Besides constraining the total amount of carbon that can be converted into biomass during the productive season (Codispoti et al., 2013), nutrients also play an important role since they determine algal photoadaptation (Sakshaug and Slagstad, 1991). During our cruise we identified three different nutrient regimes from integrated molar ratios over the euphotic zone at the end of the productive season (Fig. 3; Table 3). Along the ice margin in the Nansen Basin in August, silicate was the most depleted nutrient with $\mathrm{N}$ : Si ratios as high as 3 (Fig. 3), which were also reported for the year 1994 by Gosselin et al. (1997). This may be due to nitrate input from Atlantic waters (Rudels, 2012), but little is known about upward nutrient mixing rates. In the area adjacent to the Laptev Sea, silicate concentrations were higher, probably due to the large seasonal riverine input (Le Fouest et al., 2013), with N : Si ratios below 1 and N : P ratios (1-9) below Redfield (16), indicating nitrate depletion. In late September north of $85^{\circ} \mathrm{N}$, all depth-integrated nutrient concentrations were low (Table 3). This indicates a general nutrient and light depletion typical of the end of the season (Wheeler et al., 1997), partly due to the reduced depth of the euphotic zone $(7-15 \mathrm{~m})$.

When calculating the annual new production from nutrient drawdown for the Eurasian Basin in 2012, estimates derived from nitrogen and phosphate yield similar results (1$17 \mathrm{~g} \mathrm{C} \mathrm{m}^{-2} \mathrm{yr}^{-1}$ ), which are in accordance with the latest maximum net community production estimate for this region (14 $\mathrm{g} \mathrm{C} \mathrm{m}^{-2} \mathrm{yr}^{-1}, n=6$; Codispoti et al., 2013). Estimates derived from silicate, using a C:Si ratio of 7 (Brzezinski, 1985; Harrison et al., 1977), yield annual NPP rates half of the estimates derived from nitrogen or phosphate, suggesting that diatom production makes up for about $50 \%$ of annual new production, as biogenic silica is the main component of diatom frustules (Martin-Jézéquel et al., 2000). Assuming that sea-ice algae would contribute the most to silicate uptake during the growth season and that they have a higher
$\mathrm{C}: \mathrm{Si}$ ratio as measured at the end of the season, the contribution of diatoms to annual production would increase up to $70 \%$. However, diatoms typically have close to Redfield carbon to nutrient ratios during the growing season when nutrients are available. The observed N : Si ratios (Fig. 3) suggest that nitrate was limiting NPP in the Amundsen Basin (from the Laptev Sea slope to the North Pole), but silicate was limiting NPP in the Nansen Basin (close to the ice margin in the Kara and Barents sectors) of the Eurasian Basin, that is influenced by Atlantic waters. Thus, diatoms are probably limited in the Nansen Basin as soon as the first spring bloom has consumed all the silicate in the mixed layer. Indeed, the increase in NPP and biomass of the diatom Chaetoceros socialis in a sample from the water below the ice at the ice margin, after silicate addition, supports this idea (Figs. 5a, b, 6a, 7a).

Taking into account the export of sub-ice algae earlier in the season 2012 (average $9 \mathrm{~g} \mathrm{C} \mathrm{m}^{-2}$; Boetius et al., 2013) and the C:Si molar ratio of diatoms (7), an average of $107 \mathrm{mmol} \mathrm{Si} \mathrm{m}^{-2}$ had already been removed from surface waters before August. Since sea-ice-algal production starts earlier than phytoplankton productivity (Søreide et al., 2006), sea-ice algae might contribute to nutrient removal in surface waters at the beginning of the season leaving reduced nutrient concentrations for the phytoplankton bloom. However, since most of the sea ice in the central Arctic Ocean originates in the shelf areas of the Eurasian Basin and is then transported by the transpolar drift (Pfirman et al., 1997), the sub-ice algae growing attached to the bottom of the ice might have access to the nutrients mixed up on the shelves, upwelled at the shelf edge or ice edge earlier in the season and to the surface nutrients of a wider area while they drift with the ice (Carmack et al., 2006; Cota et al., 1990; Fernández-Méndez et al., 2014; Syvertsen, 1991). This, together with the capability of ice algae to store nutrients (Kamp et al., 2011), might provide them with an advantage over phytoplankton. 
Besides the bottom-up control of primary production, there are other factors limiting the amount of biomass present in the ice or the water column, such as grazing. Arctic zooplankton and under-ice fauna are known to feed on sea-ice algae and phytoplankton (Hop et al., 2011; Søreide et al., 2006), transferring the fixed carbon to higher trophic levels. In the central Arctic Ocean grazing has been reported to consume $15 \%$ of NPP (Olli et al., 2007). At the time of sampling, the theoretical carbon demand of the dominant zooplankton and under-ice grazers (Calanus spp. and the ice amphipod Apherusa glacialis) was on average $19 \mathrm{mg} \mathrm{C} \mathrm{m}^{-2} \mathrm{~d}^{-1}$ in the Eurasian Basin calculated from all stations investigated in this study (David et al., 2015). This would correspond to more than $80 \%$ of the mean daily NPP measured in ice-covered areas, indicating that algal biomass could periodically be significantly controlled by grazers in the central Arctic Ocean, especially at the end of the productive season. The total POC export fluxes measured in August/September with short-time sediment traps was $31 \mathrm{mg} \mathrm{C} \mathrm{m}^{-2} \mathrm{~d}^{-1}$ on average (Lalande et al., 2014), which is higher than the average INPP measured in situ $\left(24 \mathrm{mg} \mathrm{C} \mathrm{m}^{-2} \mathrm{~d}^{-1}\right)$. However, the carbon flux was mainly composed of debris and the few algae observed in the sediment traps using light microscopy were flagellates. According to seafloor observations in 2012 in the same area, the largest amount of algal carbon export had occurred already in June/July in 2012 during the main melting event, and was due to the productivity of sub-ice-algal communities (Boetius et al., 2013). These results suggest that the system was predominantly heterotrophic at the time of sampling.

Using the CAOPP model and according to the light fluxes calculated by Arndt and Nicolaus (2014), we estimate that $88 \%$ of the annual PP occurs between May and July, and only $12 \%$ in August and September, using late summer NPP rates and biomass measurements to extrapolate to the earlier part of the season. The CAOPP model estimate matches very well with our estimates based on in situ NPP in August and September, and with the annual new production estimate based on nitrate drawdown, where we estimate that $15 \%$ of the annual PP occurs in late summer and the rest earlier in the season. A more elaborate model taking into consideration quick changes in photosynthetic parameters, grazing and seasonal shifts in standing stock and nutrient availability (Palmer et al., 2014) would be necessary to improve these estimates and to more accurately simulate primary productivity under different scenarios. However, a better understanding of the future of productivity in the central Arctic Ocean foremost depends on better biological ground truth data for the entire season.

\subsection{Effects of sea-ice reduction on primary production in the central Arctic Ocean}

An increase in open-water NPP due to sea-ice retreat has already been predicted by satellite derived and in situ data in the Eurasian Arctic (Arrigo and van Dijken, 2011; Vetrov and Romankevich, 2014), especially in the Kara and Barents seas (Pabi et al., 2008). However, changes in productivity in sea-ice and in water under the ice cannot be detected by satellites. In September 2012, during our cruise, sea-ice extent reached its lowest ever recorded (Parkinson and Comiso, 2013). Another model study predicted enhanced productivity in the East Siberian and Laptev seas due to the great summer cyclone (Zhang et al., 2014). By comparing our results with previous estimates from the Eurasian Basin and recent syntheses of all PP data available (Codispoti et al., 2013; Hill et al., 2013; Matrai et al., 2013), we tried to assess the impact of sea-ice retreat on NPP. The sea-ice retreat in 2012 in the Eurasian Basin increased the open-water area in August-September by $45 \%$ compared to earlier years. The INPP rates measured in the open waters of the Laptev region $\left(84 \pm 38 \mathrm{mg} \mathrm{C} \mathrm{m}^{-2} \mathrm{~d}^{-1}\right)$ are higher than INPP measurements from the same area using the same method in August 1995, when most of the Laptev Sea area was ice covered (21 $\pm 8 \mathrm{mg} \mathrm{C} \mathrm{m}^{-2} \mathrm{~d}^{-1}$; Grossmann and Gleitz, unpublished measurements from R/V Polarstern expedition ARK XI/1). The average from satellite data from 2003 to 2012 for open waters of this region $\left(71 \mathrm{mg} \mathrm{C} \mathrm{m}^{-2} \mathrm{~d}^{-1}\right.$; Vetrov and Romankevich, 2014) is also slightly lower than our measurements during the sea-ice record minimum. No error ranges were provided for these earlier observations; hence, it remains uncertain if they indicate significant temporal changes.

As retreating sea ice leaves behind more open-water areas in summer, different Arctic regions are expected to react differently to the increase in irradiance received (Arrigo et al., 2008). To test this, we removed the ice cover in our forcing input data from our CAOPP model - mimicking predicted sea ice conditions for 2050 - and compared the results from September with our 2012 results (Table 5; Figs. 11 and 13). Based on the changes in light penetrating through the ice and assuming no change in nutrient availability, total INPP for September would increase by $292 \%$ in the Greenland sector, $56 \%$ in the Barents, $38 \%$ in the Laptev and $23 \%$ in the Kara sector of the central Arctic Ocean north of $78^{\circ} \mathrm{N}$ (Fig. 13; Table 5). These increases represent only 10-15\% of the seasonal NPP in these regions according to our model and directly represent the higher INPP in open waters. The relationship between sea ice decrease and INPP increase also arises when comparing the model results of 1982 and 2012. In this case, for the entire Eurasian Basin, a $45 \%$ decrease in the ice cover leads to a doubling in the September INPP. In the Amerasian Basin, similar increases in phytoplankton annual production have been predicted mainly due to earlier sea ice retreat (Arrigo et al., 2008; Kahru et al., 2011). However, the loss of ice-attached biomass, such as sub-ice-algal aggregates which are not taken into account in these calculations, might counteract the increase in water column PP as sea ice disappears. The regional variability of changes is due to different sea-ice coverage of the different areas. However, sea-ice retreat will affect not only light transmission 
but also water column stratification that might hinder nutrient upwelling (Codispoti et al., 2013). Depending on the future role of winds and sea-ice drift vs. stratification by freshening and warming, nutrient availability in the euphotic zone could change. For example, if ice formation occurs later in September, and if winds would also increase and cause upwelling, a second productivity peak might be observed at the end of the season (Ardyna et al., 2014). In contrast, if stratification increases, less nutrients would be available, resulting in a decrease in NPP for the month of September. Sea-icealgal productivity would likely increase and shift to earlier periods of the year, and their rapid export from the melting of their habitat in July and August will decrease nutrient availability (Boetius et al., 2013; Lalande et al., 2009). The phytoplankton community will probably shift from diatoms towards small picoplankton due to the freshening of the upper layers (Li et al., 2009), especially in the silicate limited area of the Eurasian Basin, where small picoplankton is already present (Kilias et al., 2013), and would be more nutrient efficient at low silicate concentrations. This shift in the phytoplankton community together with the disappearance of the sea-ice communities could have potentially detrimental consequences for the Arctic food web (Bhatt et al., 2014).

\subsection{Limitations and uncertainties of Arctic NPP estimates}

The central Arctic Ocean remains one of the most challenging environments to sample due to its remoteness and the year-round ice cover on top of its deep basins. The majority of Arctic NPP estimates are from seasonally ice-free waters, mainly shelves, sampled during the spring or summer months (Hill et al., 2013; Matrai et al., 2013). Ice-associated NPP has been widely neglected in previous Arctic PP estimates, because it can not be assessed remotely via satelliteborne sensors (Arrigo and van Dijken, 2011), and also due to methodological and logistical problems to measure it in the field (Matrai et al., 2013). Uncertainties of 2 orders of magnitude in NPP estimates for the central Arctic Ocean reflect the high spatial and temporal variability characteristic for this environment (Tremblay et al., 2012). Thus, it remains difficult to establish regionally representative baselines in Arctic NPP, to be able to detect significant changes in productivity related to the ongoing sea-ice retreat.

This study provides summer in situ NPP data from the under-sampled Eurasian Basin including water column, sea ice and melt pond that can be used to validate ocean general circulation models predicting changes in Arctic PP (Ferland et al., 2011; Tremblay et al., 2012). Photosynthetic parameters derived from PI curves under realistic conditions are important for modelling primary productivity (Popova et al., 2012; Vancoppenolle et al., 2013). A combination of in situ obtained photosynthetic parameters and a light parameterization for light transmittance of sea ice (CAOPP model) enabled us to estimate INPP for the entire Eurasian Basin, including ice-covered areas (Fig. 11). Although the CAOPP model does not include nutrient information, the PI curves were measured at the end of the season in nutrient limited waters. Hence, using the same parameters to model PP earlier in the season, when more nutrients are available, will underestimate productivity. Photosynthetic parameters vary locally, seasonally and vertically as well as horizontally in the water column and in the sea ice (Behrenfeld and Falkowski, 1997; Duarte et al., 2015; Palmer et al., 2014). Therefore, the photosynthetic parameters cover a wide range (Table 2) and are not well constrained. This leads to 2 orders of magnitude difference between the minimum and the maximum NPP calculated with the model. To constrain the results further, more in situ measurements are needed to capture the regional and temporal variability in photosynthetic parameters.

In addition, nitrate vs. ammonium uptake rates should be included in such studies to estimate the importance of new versus regenerated production at each period of the productive season (Dugdale and Goering, 1967; Tremblay and Gagnon, 2009). With our approaches, the in situ measurements in late summer were probably mainly measuring regenerated production, while the annual estimates of production based on nutrient drawdown is only taking into account the new production.

Another limitation of our upscaling using the CAOPP model is that the light parameterization assumes a constant extinction coefficient in the water column and is not spectrally resolved (Manes and Gradinger, 2009; Palmer et al., 2011; Sakshaug and Slagstad, 1991). This could lead to NPP overestimation in open-water coastal areas (Alver et al., 2014). A recent INPP estimate for the Arctic Ocean Basin including the Amerasian Basin based on NPP measurements only in ice-free waters $\left(0.4 \mathrm{Tg} \mathrm{C} \mathrm{month}^{-1}\right.$ (Arrigo et al., 2011; Bélanger et al., 2013) is at the lower end of our estimated range for the water under the ice in the Eurasian Basin in August (0.2-6.8 Tg C month ${ }^{-1}$ ), but suggests that our model can give realistic estimates. Seasonality remains a critical issue in the central Arctic Ocean since there are still no measurements of early spring photosynthetic parameters from communities thriving in and under the ice. Assessing the algal biomass below the ice using automated autonomous systems such as ice tethered profiles (ITPs) that drift with the ice during an entire year might be an important step forward to improve our understanding of the annual cycle of primary production in the central basins (Laney et al., 2014).

\section{Conclusions}

The central Arctic Ocean basins have been generally regarded as low productivity areas. Due to their inaccessibility they have remained largely under-sampled leading to a lack of baseline data to assess current changes. This study provides measurements of primary production during the record sea-ice minimum in the Eurasian Basin in 2012, and new es- 
timates for all environments where phototrophs thrive: sea ice, melt ponds and water column. Sea-ice algae contributed up to $60 \%$ to the total INPP in the central Arctic Ocean at the end of the productive season. Comparing our measured estimates from 2012 with previous estimates of NPP in the central Arctic Ocean, we conclude that an overall change in NPP magnitude would be foremost related to a change in the role of the ice-algal production and export of sub-ice-algal aggregates. INPP in melt ponds can contribute up to $34 \%$ locally, but at a larger scale their contribution to INPP is $<4 \%$, excluding local aggregations of sea-ice algae. Ice-covered waters sustain lower NPP than open waters in the late summer season, indicating light limitation. However, over the annual productive period, the role of sub-ice algae may be increasing with the overall thinning of sea ice. Therefore, an increase in irradiance transmitted through the ice will probably lead to an increase in both ice and water column NPP in the central basins and a shift in timing towards earlier sea-ice NPP. These shifts in the timing and location of ice-algal blooms are likely to impact life cycle strategies and community composition of zooplankton and under-ice fauna, with unknown consequences for the under ice food-web and export fluxes. However, nutrients will still constrain the annual budget of new production both for sea-ice algae and phytoplankton. In the Eurasian Basin, nitrate limits NPP in the Amundsen Basin and silicate limits diatom-based NPP at the ice margin near the Atlantic water inflow (Nansen Basin) at the end of the productive season. Better understanding of the overall development of Arctic productivity will need year-round longterm observations of nutrient supplies and light availability, as well as of mixing processes and grazer populations.

\section{The Supplement related to this article is available online at doi:10.5194/bg-12-3525-2015-supplement.}

Author contributions. M. Fernández-Méndez and A. Boetius designed the experiments, C. Katlein and M. Nicolaus carried out the modelling, K. Bakker, I. Peeken, B. Rabe and H. Flores provided data. M. Fernández-Méndez wrote the manuscript with input from $\mathrm{AB}$ and all coauthors.

Acknowledgements. We would like to thank the captain and the crew of R/V POLARSTERN ARK XXVII/3 for their support during the expedition. We thank Gerhard Dieckmann, Victor Smetacek, Philipp Assmy and Catherine Lalande for fruitful discussions. We also thank Stefanie Arndt for her help with the light parameterization. The technical assistance of Christiane Lorenzen, Rafael Stiens and Jölund Asseng is greatly appreciated. Finally, we thank Mathieu Ardyna and Michel Gosselin for sharing all the AOS data with us. This study was supported by the Alfred-Wegener-Institut Helmholtz-Zentrum für Polar- und Meeresforschung and the Max Planck Society, as well as the ERC Advanced Grant Abyss (no. 294757) to AB, and the "Transdrift Project" of the BMBF (no. 03G0833B).
The article processing charges for this open-access publication were covered by the Max Planck Society.

Edited by: E. Marañón

\section{References}

Alver, M. O., Hancke, K., Sakshaug, E., and Slagstad, D.: A spectrally-resolved light propagation model for aquatic systems: Steps toward parameterizing primary production, J. Mar. Syst., 130, 134-146, doi:10.1016/j.jmarsys.2012.03.007, 2014.

Andersen, S., Breivik, L. A., Eastwood, S., Godøy, Ø., Lind, M., Porcires, M. and Schyberg, H.: OSI SAF Sea Ice Product Manual v3.5 Tech. Rep. SAF/OSI/met. no/TEC/MA/125, EUMETSAT OSI SAF, Ocean and Sea Ice Sattelite Application Facility, 2007.

Ardyna, M., Gosselin, M., Michel, C., Poulin, M., and Tremblay, J.-É.: Environmental forcing of phytoplankton community structure and function in the Canadian High Arctic: contrasting oligotrophic and eutrophic regions, Mar. Ecol. Prog.-Ser., 442, 3757, doi:10.3354/meps09378, 2011.

Ardyna, M., Babin, M., Gosselin, M., Devred, E., Rainville, L., and Tremblay, J.-É.: Recent Arctic Ocean sea-ice loss triggers novel fall phytoplankton blooms, Geophys. Res. Lett., 41, 6207-6212, doi:10.1002/2014GL061047, 2014.

Arndt, S. and Nicolaus, M.: Seasonal cycle and long-term trend of solar energy fluxes through Arctic sea ice, Cryosph., 8, 22192233, doi:10.5194/tc-8-2219-2014, 2014.

Arrigo, K. R.: Sea ice ecosystems, Ann. Rev. Mar. Sci., 6, 439-467, doi:10.1146/annurev-marine-010213-135103, 2014.

Arrigo, K. R. and van Dijken, G. L.: Secular trends in Arctic Ocean net primary production, J. Geophys. Res., 116, C09011, doi:10.1029/2011JC007151, 2011.

Arrigo, K. R., van Dijken, G., and Pabi, S.: Impact of a shrinking Arctic ice cover on marine primary production, Geophys. Res. Lett., 35, L19603, doi:10.1029/2008GL035028, 2008.

Arrigo, K. R., Matrai, P. A., and van Dijken, G. L.: Primary productivity in the Arctic Ocean: Impacts of complex optical properties and subsurface chlorophyll maxima on large-scale estimates, J. Geophys. Res., 116, C11022, doi:10.1029/2011JC007273, 2011.

Bakker, K.: Nutrients measured on water bottle samples during POLARSTERN cruise ARK-XXVII/3 (IceArc) in 2012, unpublished dataset \#834081, Texel, 2014.

Behrenfeld, M. J. and Falkowski, P. G.: A consumers guide to phytoplankton primary productivity models, Limnol. Oceanogr., 42, 1479-1491, 1997.

Bélanger, S., Babin, M., and Tremblay, J.-É.: Increasing cloudiness in Arctic damps the increase in phytoplankton primary production due to sea ice receding, Biogeosciences, 10, 4087-4101, doi:10.5194/bg-10-4087-2013, 2013.

Bhatt, U. S., Walker, D. A., Walsh, J. E., Carmack, E. C., Frey, K. E., Meier, W. N., Moore, S. E., Parmentier, F. W., Post, E., Romanovsky, V. E., and Simpson, W. R.: Implications of arctic sea ice decline for the Earth System, Annu. Rev. Environ. Resour., 39, 1-33, doi:10.1146/annurev-environ-122012-094357, 2014.

Boetius, A., Albrecht, S., Bakker, K., Bienhold, C., Felden, J., Fernández-Méndez, M., Hendricks, S., Katlein, C., Lalande, C., Krumpen, T., Nicolaus, M., Peeken, I., Rabe, B., Rogacheva, 
A., Rybakova, E., Somavilla, R., Wenzhöfer, F., and RV Polarstern ARK27-3-Shipboard Science Party: Export of algal biomass from the melting Arctic sea ice, Science, 339, 14301432, doi:10.1126/science.1231346, 2013.

Brzezinski, M. A.: The $\mathrm{Si}: \mathrm{C}: \mathrm{N}$ ratio of marine diatoms: internespecific variability and the effect of some environmental variables, J. Phycol., 21, 347-357, 1985.

Carmack, E., Barber, D., Christensen, J., Macdonald, R., Rudels, B. and Sakshaug, E.: Climate variability and physical forcing of the food webs and the carbon budget on panarctic shelves, Prog. Oceanogr., 71, 145-181, doi:10.1016/j.pocean.2006.10.005, 2006.

Codispoti, L. A. A. L. A., Kelly, V., Thessen, A., Matrai, P., Suttles, S., Hill, V., Steele, M. and Light, B.: Synthesis of primary production in the Arctic Ocean: III . Nitrate and phosphate based estimates of net community production, Prog. Oceanogr., 110, 126-150, doi:10.1016/j.pocean.2012.11.006, 2013.

Cota, G. F.: Photoadaptation of high Arctic ice algae, Nature, 315, 219-222, 1985.

Cota, G. F., Anning, J. L., Harris, L. R., Harrison, W. G., and Smith, R. E. H.: Impact of ice algae on inorganic nutrients in seawater and sea Ice in Barrow Strait, NWT, Canada, during spring, Can. J. Fish. Aquat. Sci., 47, 1402-1415, doi:10.1139/f90-159, 1990.

Cota, G. F., Pomeroy, L. R., Harrison, W. G., Jones, E. P., Peters, F., Sheldon, W. M., and Weingartner, T. R.: Nutrients, primary production and microbial heterotrophy in the southeastern Chukchi Sea: Arctic summer nutrient depletion and heterotrophy, Mar. Ecol. Prog.-Ser., 135, 247-258, 1996.

David, C., Flores, H., Lange, B., and Rabe, B.: Community structure of under-ice fauna in the Eurasian central Arctic Ocean in relation to environmental properties of sea ice habitats, Mar. Ecol. Prog.-Ser., 522, 15-32, doi:10.3354/meps11156, 2015.

Dee, D., Uppala, S., Simmons, A., Berrisford, P., Poli, P., Kobayashi, S., Andrae, U., Balmaseda, M., Balsamo, G., and Bauer, P.: The ERA-Interim reanalysis: Configuration and performance of the data assimilation system., Q. J. Roy. Meteorol. Soc., 137, 553-597, 2011.

Duarte, P., Assmy, P., Hop, H., Spreen, G., Gerland, S., and Hudson, S. R.: The importance of vertical resolution in sea ice algae production models, J. Mar. Syst., 145, 69-90, doi:10.1016/j.jmarsys.2014.12.004, 2015.

Dugdale, R. C. and Goering, J. J.: Uptake of new and regenerated forms of nitrogen in primary productivity, Limnol. Oceanogr., 12, 196-206, 1967.

Dupont, F.: Impact of sea-ice biology on overall primary production in a biophysical model of the pan-Arctic Ocean, J. Geophys. Res., 117, C00D17, doi:10.1029/2011JC006983, 2012.

Ehn, J. K. and Mundy, C. J.: Assessment of light absorption within highly scattering bottom sea ice from underice light measurements: Implications for Arctic ice algae primary production, Limnol. Oceanogr., 58, 893-902, doi:10.4319/lo.2013.58.3.0893, 2013.

Ferland, J., Gosselin, M., and Starr, M.: Environmental control of summer primary production in the Hudson Bay system: The role of stratification, J. Mar. Syst., 88, 385-400, doi:10.1016/j.jmarsys.2011.03.015, 2011.

Fernández-Méndez, M., Wenzhöfer, F., Peeken, I., Sørensen, H. L., Glud, R. N., and Boetius, A.: Composition, buoyancy regulation and fate of ice algal aggregates in the Central Arctic Ocean, PLoS One, 9, e107452, doi:10.1371/journal.pone.0107452, 2014.

Frigstad, H., Andersen, T., Bellerby, R. G. J., Silyakova, A., and Hessen, D. O.: Variation in the seston C:N ratio of the Arctic Ocean and pan-Arctic shelves, J. Mar. Syst., 129, 214-223, doi:10.1016/j.jmarsys.2013.06.004, 2014.

Gosselin, M., Levasseur, M., Wheeler, P. A., Horner, R. A., and Boothg, B. C.: New measurements of phytoplankton and ice algal production in the Arctic Ocean, Deep-Sea Res. Pt. II, 44, 1623 1644, doi:10.1016/S0967-0645(97)00054-4, 1997.

Gradinger, R.: Sea-ice algae: Major contributors to primary production and algal biomass in the Chukchi and Beaufort Seas during May/June 2002, Deep-Sea Res. Pt. II, 56, 1201-1212, doi:10.1016/j.dsr2.2008.10.016, 2009.

Gradinger, R., Friedrich, C., and Spindler, M.: Abundance, biomass and composition of the sea ice biota of the Greenland Sea pack ice, Deep-Sea Res. Pt. II, 46, 1457-1472, doi:10.1016/S09670645(99)00030-2, 1999.

Haas, C., Lobach, J., Hendricks, S., Rabenstein, L., and Pfaffling, A.: Helicopter-borne measurements of sea ice thickness, using a small and lightweight, digital EM bird, J. Appl. Geophys., 67, 234-241, doi:10.1016/j.jappgeo.2008.05.005, 2009.

Hall, P. O. J. and Aller, R. C.: Rapid, small-volume, flow injection analysis for $\mathrm{CO}_{2}$ and $\mathrm{NH}_{4}^{+}$in marine and freshwaters, Limnol. Oceanogr., 37, 1113-1119, 1992.

Harrison, P. J., Conway, H. L., Holmes, R. W., and Davis, C. O.: Marine diatoms grown in chemostats under silicate or ammonium limitation, III. Cellular chemical composition and morphology of Chaetoceros debilis, Skeletonema costatum, and Thalassiosira gravida, Mar. Biol., 43, 19-31, doi:10.1007/BF00392568, 1977.

Hendricks, S., Nicolaus, M., and Schwegmann, S.: Sea ice conditions during POLARSTERN cruise ARK-XXVII/3 (IceArc), Alfred Wegener Institute, Helmholtz Center for Polar and Marine Research, Bremerhaven, doi:10.1594/PANGAEA.803221, 2012

Hill, V. J., Matrai, P. A., Olson, E., Suttles, S., Steele, M., Codispoti, L. A., and Zimmerman, R. C.: Synthesis of integrated primary production in the Arctic Ocean: II. In situ and remotely sensed estimates, Prog. Oceanogr., 110, 107-125, doi:10.1016/j.pocean.2012.11.005, 2013.

Hop, H., Mundy, C. J., Gosselin, M., Rossnagel, A. L., and Barber, D. G.: Zooplankton boom and ice amphipod bust below melting sea ice in the Amundsen Gulf, Arctic Canada, Polar Biol., 34, 1947-1958, doi:10.1007/s00300-011-0991-4, 2011.

Jones, E. P., Anderson, L. G., and Swift, J. H.: Distribution of Atlantic and Pacific waters in the upper Arctic Ocean: Implications for circulation distinguish between oceanic waters of $\mathrm{Pa}$ cific, Geophys. Res. Lett., 25, 765-768, 1998.

Juhl, A. R. and Krembs, C.: Effects of snow removal and algal photoacclimation on growth and export of ice algae, Polar Biol., 33, 1057-1065, 2010.

Kahru, M., Brotas, V., Manzano-Sarabia, M., and Mitchell, B. G.: Are phytoplankton blooms occurring earlier in the Arctic?, Global Change Biol., 17, 1733-1739, doi:10.1111/j.13652486.2010.02312.x, 2011.

Kamp, A., de Beer, D., Nitsch, J. L., Lavik, G., and Stief, P.: Diatoms respire nitrate to survive dark and anoxic conditions, P. Natl. Acad. Sci. USA, 108, 5649-5654, doi:10.1073/pnas.1015744108, 2011. 
Katlein, C., Fernández-Méndez, M., Wenzhöfer, F., and Nicolaus, M.: Distribution of algal aggregates under summer sea ice in the Central Arctic, Polar Biol., 1634, doi:10.1007/s00300-014-16343, 2014a.

Katlein, C., Nicolaus, M., and Petrich, C.: The anisotropic scattering coefficient of sea ice, J. Geophys. Res., 119, 842-855, doi:10.1002/2013JC009502, 2014b.

Kilias, E., Wolf, C., Nöthig, E.-M., Peeken, I., and Metfies, K.: Protist distribution in the Western Fram Strait in summer 2010 based on 454-pyrosequencing of 18S rDNA, J. Phycol., 49, 995-1010, doi:10.1111/jpy.12109, 2013.

Korhonen, M., Rudels, B., Marnela, M., Wisotzki, A., and Zhao, J.: Time and space variability of freshwater content, heat content and seasonal ice melt in the Arctic Ocean from 1991 to 2011, Ocean Sci., 9, 1015-1055, doi:10.5194/os-9-1015-2013, 2013.

Kramer, M. and Kiko, R.: Brackish meltponds on Arctic sea ice a new habitat for marine metazoans, Polar Biol., 34, 603-608, doi:10.1007/s00300-010-0911-z, 2011.

Lalande, C., Bélanger, S., and Fortier, L.: Impact of a decreasing sea ice cover on the vertical export of particulate organic carbon in the northern Laptev Sea, Siberian Arctic Ocean, Geophys. Res. Lett., 36, L21604, doi:10.1029/2009GL040570, 2009.

Lalande, C., Bauerfeind, E., Nöthig, E.-M., and BeszczynskaMöller, A.: Impact of a warm anomaly on export fluxes of biogenic matter in the eastern Fram Strait, Prog. Oceanogr., 109, 70-77, doi:10.1016/j.pocean.2012.09.006, 2013.

Lalande, C., Nöthig, E.-M., Somavilla, R., Bauerfeind, E., Schevschenko, V., Okolodkov, Y., Shevshenko, V., and Shevchenko, V.: Variability in under-ice export fluxes of biogenic matter in the Arctic Ocean, Global Biogeochem. Cy., 28, 1-13, doi:10.1002/2013GB004735, 2014.

Laney, S. R., Krishfield, R. A., Toole, J. M., Hammar, T. R., Ashjian, C. J., and Timmermans, M.-L.: Assessing algal biomass and bio-optical distributions in perennially icecovered polar ocean ecosystems, Polar Sci., 8, 73-85, doi:10.1016/j.polar.2013.12.003, 2014.

Lange, B., Beckers, J., Alec, C., Flores, H., Meisterhans, G., Niemi, A., Haas, C., and Michel, C.: Comparison of biogeochemical and physical properties of multi-year and first-year sea ice in the Lincoln Sea., J. Geophys. Res., 10, e0122418, doi:10.1371/journal.pone.0122418, 2015.

Laxon, S. W., Giles, K. A., Ridout, A. L., Wingham, D. J., Willatt, R., Cullen, R., Kwok, R., Schweiger, A., Zhang, J., Haas, C., Hendricks, S., Krish, R., Kurtz, N., Farrell, S., and Davidson, M.: CryoSat-2 estimates of Arctic sea ice thickness and volume, Geophys. Res. Lett., 40, 1-6, doi:10.1002/GRL.50193, 2013.

Lee, S. H., Mcroy, C. P. P., Joo, H. M., Gradinger, R., Cui, X., Yun, M. S., Chung, K. H., Choy, E. J., Son, S., Carmack, E., and Whitledge, T. E.: Holes in progressively thinning Arctic sea ice lead to new ice algal habitat, Oceanography, 24, 302-308, doi:10.5670/oceanog.2011.81, 2011.

Lee, S. H., Stockwell, D. A., Joo, H., Son, Y. B., Kang, C., and Whitledge, T. E.: Phytoplankton production from melting ponds on Arctic sea ice, J. Geophys. Res., 117, C04030, doi:10.1029/2011JC007717, 2012.

Le Fouest, V., Babin, M., and Tremblay, J.-É.: The fate of riverine nutrients on Arctic shelves, Biogeosciences, 10, 3661-3677, doi:10.5194/bg-10-3661-2013, 2013.
Legendre, L., Horner, R., Ackley, S. F., Dieckmann, G. S., Gulliksen, B., Hoshiai, T., Melnikov, I. A., Reeburgh, W. S., Spindler, M., and Sullivan, C. W.: Ecology of sea ice biota: 2. Global significance, Polar Biol., 12, 429-444, doi:10.1007/BF00243113, 1992.

Leu, E., Wiktor, J., Søreide, J., Berge, J., and Falk-Petersen, S.: Increased irradiance reduces food quality of sea ice algae, Mar. Ecol. Prog.-Ser., 411, 49-60, doi:10.3354/meps08647, 2010.

Leu, E., Søreide, J. E. E., Hessen, D. O. O., Falk-Petersen, S., and Berge, J.: Consequences of changing sea-ice cover for primary and secondary producers in the European Arctic shelf seas: Timing, quantity, and quality, Prog. Oceanogr., 90, 18-32, doi:10.1016/j.pocean.2011.02.004, 2011.

Li, W. K. W., McLaughlin, F. A., Lovejoy, C., and Carmack, E. C.: Smallest algae thrive as the Arctic Ocean freshens, Science, 326, 5952, doi:10.1126/science.1179798, 2009.

Lindsay, R. and Schweiger, A.: Arctic sea ice thickness loss determined using subsurface, aircraft, and satellite observations, The Cryosphere, 9, 269-283, doi:10.5194/tc-9-269-2015, 2015.

Lund-Hansen, L. C., Hawes, I., Sorrell, B. K., and Nielsen, M. H.: Removal of snow cover inhibits spring growth of Arctic ice algae through physiological and behavioral effects, Polar Biol., 37, 471-481, 2014.

Maestrini, S. Y., Rochet, M., Legendre, L., and Demers, S.: Nutrient limitation of the bottom-ice microalgal biomass (Southeastern Hudson Bay, Canadian Arctic), Limnol. Oceanogr., 31, 969982, 1986.

Manes, S. S. and Gradinger, R.: Small scale vertical gradients of Arctic ice algal photophysiological properties, Photosynth. Res., 102, 53-66, doi:10.1007/s11120-009-9489-0, 2009.

Martin, J., Tremblay, J. É., and Price, N. M.: Nutritive and photosynthetic ecology of subsurface chlorophyll maxima in Canadian Arctic waters, Biogeosciences, 9, 5353-5371, doi:10.5194/bg-95353-2012, 2012.

Martin-Jézéquel, V., Copernic, P. N., Plouzane, F., Brzezinski, M. A., and Hildebrant, M.: Silicon metabolism in diatoms: implications for growth, J. Phycol., 36, 821-840, 2000.

Maslanik, J. A., Fowler, C., Stroeve, J., Drobot, S., Zwally, J., Yi, D., and Emery, W.: A younger, thinner Arctic ice cover: increased potential for rapid, extensive sea-ice loss, Geophys. Res. Lett., 34, L24501, doi:10.1029/2007GL032043, 2007.

Matrai, P. and Apollonio, S.: New estimates of microalgae production based upon nitrate reductions under sea ice in Canadian shelf seas and the Canada Basin of the Arctic Ocean, Mar. Biol., 160, 1297-1309, doi:10.1007/s00227-013-2181-0, 2013.

Matrai, P., Olson, E., Suttles, S., Hill, V. J., Codispoti, L. A., Light, B., Steele, M., Boothbay, E., Hole, W. ,and Sciences, A.: Synthesis of primary production in the Arctic Ocean: I. Surface waters, Prog. Oceanogr., 110, 93-106, doi:10.1016/j.pocean.2012.11.004, 2013.

Michel, C., Legendre, L., Demers, S., and Therriault, J.-C.: Photoadaptation of sea-ice microalgae in springtime: photosynthesis and carboxylating enzymes, Mar. Ecol. Prog.-Ser., 50, 177-185, 1988.

Mikkelsen, D. M., Rysgaard, S., and Glud, R. N.: Microalgal composition and primary production in Arctic sea ice: a seasonal study from Kobbefjord (Kangerluarsunnguaq), West Greenland, Mar. Ecol. Prog.-Ser., 368, 65-74, doi:10.3354/meps07627, 2008. 
Miller, L. A., Fripiat, F., Else, B. G. T., Bowman, J. S., Brown, K. a., Collins, R. E., Ewert, M., Fransson, A., Gosselin, M., Lannuzel, D., Meiners, K. M., Michel, C., Nishioka, J., Nomura, D., Papadimitriou, S., Russell, L. M., Sørensen, L. L., Thomas, D. N., Tison, J.-L., van Leeuwe, M. a., Vancoppenolle, M., Wolff, E. W., and Zhou, J.: Methods for biogeochemical studies of sea ice: The state of the art, caveats, and recommendations, Elem. Sci. Anthr., 3, 000038, doi:10.12952/journal.elementa.000038, 2015.

Mundy, C., Michel, G., Jens, K. E., Claude, B., Poulin, M., Alou, E., Roy, S., Hop, H., Lessard, S., Papakyriakou, T. N., Barber, D. G., and Stewart, J.: Characteristics of two distinct highlight acclimated algal communities during advanced stages of sea ice melt, Polar Biol., 34, 1869-1886, doi:10.1007/s00300-0110998-x, 2011.

Needoba, J. A. and Harrison, P. J.: Influence of Low Light and a Light: Dark Cycle on $\mathrm{NO}_{3}$ Uptake, Intracellular $\mathrm{NO}_{3}$, and Nitrogen Isotope Fractionation By Marine Phytoplankton, J. Phycol., 40, 505-516, doi:10.1111/j.1529-8817.2004.03171.x, 2004.

Nicolaus, M., Katlein, C., Maslanik, J., and Hendricks, S.: Changes in Arctic sea ice result in increasing light transmittance and absorption, Geophys. Res. Lett., 39, L24501, doi:10.1029/2012GL053738, 2012.

NSIDC - National Snow and Ice Data Center: Report 2012, available at: http://nsidc.org/arcticseaicenews/, http://nsidc.org/news/ press/2012seaiceminimum.html (last access: 3 June 2015), 2012.

Olli, K., Wassmann, P., Reigstad, M., Ratkova, T. N., Arashkevich, E., Pasternak, A., Matrai, P. A., Knulst, J., Tranvik, L., Klais, R., and Jacobsen, A.: The fate of production in the central Arctic Ocean - top-down regulation by zooplankton expatriates?, Prog. Oceanogr., 72, 84-113, doi:10.1016/j.pocean.2006.08.002, 2007.

Pabi, S., van Dijken, G. L., and Arrigo, K. R.: Primary production in the Arctic Ocean, 1998-2006, J. Geophys. Res., 113, C08005, doi:10.1029/2007JC004578, 2008.

Palmer, M. A., Arrigo, K. R., Ehn, J. K., Mundy, C. J., Gosselin, M., Barber, D. G., Martin, J., Alou, E., Roy, S., and Tremblay, J.-É.: Spatial and temporal variation of photosynthetic parameters in natural phytoplankton assemblages in the Beaufort Sea , Canadian Arctic, Polar Biol., 34, 1915-1928, doi:10.1007/s00300011-1050-x, 2011.

Palmer, M. A., Saenz, B. T., and Arrigo, K. R.: Impacts of sea ice retreat, thinning, and melt-pond proliferation on the summer phytoplankton bloom in the Chukchi Sea, Arctic Ocean, Deep-Sea Res. Pt. II, 105, 85-104, doi:10.1016/j.dsr2.2014.03.016, 2014.

Parkinson, C. L. and Comiso, J. C.: On the 2012 record low Arctic sea ice cover: Combined impact of preconditioning and an August storm, Geophys. Res. Lett., 40, 1356-1361, doi:10.1002/grl.50349, 2013.

Parsons, T. R., Maita, Y., and Lalli, C.: A Manual of chemical and biological methods for seawater analysis, Pergamon Press, Toronto, 1984.

Perovich, D. K.: The optical properties of sea ice, Hanover, NH, 1996.

Pfirman, S. L., Colony, R., Niirnberg, D., Eicken, H., and Rigor, I.: Reconstructing the origin and trajectory of drifting Arctic sea ice, J. Geophys. Res., 102, 575-586, 1997.

Platt, T., Gallegos, C. L., and Harrison, W. G.: Photoinhibition of photosynthesis in natural assemblages of marine phytoplankton, J. Mar. Res., 38, 687-701, 1980.
Platt, T., Harrison, W. G., Irwin, B., Horne, E. P., and Gallegos, C. L.: Photosynthesis and photoadaptation of marine phytoplankton in the arctic, Deep-Sea Res., 29, 1159-1170, doi:10.1016/01980149(82)90087-5, 1982.

Popova, E. E., Yool, A., Coward, A. C., Aksenov, Y. K., Alderson, S. G., de Cuevas, B. A., and Anderson, T. R.: Control of primary production in the Arctic by nutrients and light: insights from a high resolution ocean general circulation model, Biogeosciences, 7, 3569-3591, doi:10.5194/bg-7-3569-2010, 2010.

Popova, E. E., Yool, A., Coward, A. C., Dupont, F., Deal, C., Elliott, S., Hunke, E., Jin, M., Steele, M., and Zhang, J.: What controls primary production in the Arctic Ocean? Results from an intercomparison of five general circulation models with biogeochemistry, J. Geophys. Res., 117, C00D12, doi:10.1029/2011JC007112, 2012.

Rabe, B., Wisotzki, A., Rettig, S., Somavilla Cabrillo, R., and Sander, H.: Physical oceanography measured on water bottle samples during POLARSTERN cruise ARK-XXVII/3, Alfred Wegener Institute, Helmholtz Center for Polar and Marine Research, Bremerhaven, doi:10.1594/PANGAEA.819452, 2012.

Reiniger, R. F., Ross, C. K., and Rosst, C. K.: A method of interpolation with application to oceanographic data, Deep-Sea Res., 15, 185-193, 1968.

Rintala, J.-M., Piiparinen, J., Blomster, J., Majaneva, M., Müller, S., Uusikivi, J., and Autio, R.: Fast direct melting of brackish sea-ice samples results in biologically more accurate results than slow buffered melting, Polar Biol., 37, 1811-1822, doi:10.1007/s00300-014-1563-1, 2014.

Rösel, A. and Kaleschke, L.: Exceptional melt pond occurrence in the years 2007 and 2011 on the Arctic sea ice revealed from MODIS satellite data, J. Geophys. Res., 117, C05018, doi:10.1029/2011JC007869, 2012.

Rozanska, M., Gosselin, M., Poulin, M., Wiktor, J., and Michel, C.: Influence of environmental factors on the development of bottom ice protist communities during the winter-spring transition, Mar. Ecol. Prog.-Ser., 386, 43-59, doi:10.3354/meps08092, 2009.

Rudels, B.: The thermohaline circulation of the Arctic Ocean and the Greenland Sea, Philos. Trans. Sci. Eng., 352, 287-299, 1995.

Rudels, B.: Arctic Ocean circulation and variability - advection and external forcing encounter constraints and local processes, Ocean Sci., 8, 261-286, doi:10.5194/os-8-261-2012, 2012.

Sakshaug, E. and Slagstad, D.: Light and productivity of phytoplankton in polar marine ecosystems: a physiological view, in: Proceedings of the Pro Mare Symposium on Polar Marine Ecology, vol. 1906, edited by: Sakshaug, E., Hopkins, C., and Oritsland, N., PolarResearch, Trondheim, 69-85, 1991.

Sakshaug, E., Stein, R., and Macdonald, R. W.: Primary and secondary production in the Arctic Seas, in: The Organic Carbon Cycle in the Arctic Ocean, edited by: Stein, R. and Macdonald, R. W., Springer, Berlin, Heidelberg, 57-82, doi:10.1007/978-3642-18912-8, 2004.

Sherr, E. B., Sherr, B. F., Wheeler, P. A., and Thompson, K.: Temporal and spatial variation in stocks of autotrophic and heterotrophic microbes in the upper water column of the central Arctic Ocean, Deep-Sea Res. Pt. I, 50, 557-571, doi:10.1016/S0967-0637(03)00031-1, 2003.

Simpson, K. G., Tremblay, J.-É., and Price, N. M.: Nutrient dynamics in the western Canadian Arctic. I. New production in spring inferred from nutrient draw-down in the Cape Bathurst Polynya, 
Mar. Ecol. Prog.-Ser., 484, 33-45, doi:10.3354/meps10275, 2013.

Slagstad, D., Ellingsen, I. H. H., and Wassmann, P.: Evaluating primary and secondary production in an Arctic Ocean void of summer sea ice: an experimental simulation approach, Prog. Oceanogr., 90, 117-131, doi:10.1016/j.pocean.2011.02.009, 2011.

Smith, R. E. H., Gosselin, M., and Taguchi, S.: The influence of major inorganic nutrients on the growth and physiology of high arctic ice algae, J. Mar. Syst., 11, 63-70, 1997.

Søreide, J. E., Hop, H., Carroll, M. L., Falk-Petersen, S., and Hegseth, E. N.: Seasonal food web structures and sympagicpelagic coupling in the European Arctic revealed by stable isotopes and a two-source food web model, Prog. Oceanogr., 71, 59-87, doi:10.1016/j.pocean.2006.06.001, 2006.

Spilling, K., Tamminen, T., Andersen, T., and Kremp, A.: Nutrient kinetics modeled from time series of substrate depletion and growth: dissolved silicate uptake of Baltic Sea spring diatoms, Mar. Biol., 157, 427-436, doi:10.1007/s00227-009-13294, 2010.

Spindler, M.: Notes on the biology of sea ice in the Arctic and Antarctic, Polar Biol., 14, 319-324, doi:10.1007/BF00238447, 1994.

Steemann Nielsen, E.: The use of radio-active carbon (C14) for measuring organic production in the sea, J. Cons. Int. Explor. Mer., 18, 117-140, 1952.

Stroeve, J. C., Serreze, M. C., Holland, M. M., Kay, J. E., Malanik, J., and Barrett, A. P.: The Arctic's rapidly shrinking sea ice cover: a research synthesis, Climatic Change, 110, 1005-1027, doi:10.1007/s10584-011-0101-1, 2012.

Syvertsen, E. E.: Ice algae in the Barents Sea: types of assemblages, origin, fate and role in the ice-edge phytoplankton bloom, Proc. Pro Mare Symp. Polar Mar. Ecol., 1961, 277-287, 1991.

Tamelander, T., Reigstad, M., Olli, K., Slagstad, D., and Wassmann, P.: New production regulates export stoichiometry in the ocean, PLoS One, 81, e54027, doi:10.1371/journal.pone.0054027, 2013.

Thomas, D. N. and Dieckmann, G. S.: Sea Ice, Second, edited by: Thomas, R. W. and Dieckmann, G. S., Wiley-Blackwell, West Sussex, 2010.

Tran, S., Bonsang, B., Gros, V., Peeken, I., Sarda-Esteve, R., Berhardt, A., and Belvisio, S.: A survey of carbon monoxide and non-methane hydrocarbons in the Arctic Ocean during summer 2010, Biogeosciences, 10, 1909-1935, doi:10.5194/bg-101909-2013, 2013.

Tremblay, J.-É. and Gagnon, J.: The effects of irradiance and nutrient supply on the productivity of Arctic waters: a perspective on climate change, in: Influence of Climate Change on the Changing Arctic and Sub-Arctic Conditions, edited by: Nihoul, J. and Kostianoy, A., Springer Science + Business Media B. V., Springer Netherlands, 73-93, doi:10.1007/978-1-4020-9460-6, 2009.
Tremblay, J.-É., Simpson, K., Martin, J., Miller, L., Gratton, Y., Barber, D., and Price, N. M.: Vertical stability and the annual dynamics of nutrients and chlorophyll fluorescence in the coastal, southeast Beaufort Sea, J. Geophys. Res., 113, C07S90, doi:10.1029/2007JC004547, 2008.

Tremblay, J.-É., Robert, D., Varela, D. E., Lovejoy, C., Darnis, G., Nelson, R. J., and Sastri, A. R.: Current state and changing trends in Canadian arctic marine ecosystems: I. Primary production, Climatic Change, 115, 161-178, 2012.

Ulfsbo, A., Cassar, N., Korhonen, M., Van Heuven, S., and Hoppema, M.: Late summer net community production in the central Arctic Ocean using multiple approaches, Global Biogeochem. Cy., 28, 1129-1148, doi:10.1002/2014GB004833, 2014.

Vancoppenolle, M., Bopp, L., Madec, G., Dunne, J., Ilyina, T., Halloran, P. R., and Steiner, N.: Future Arctic Ocean primary productivity from CMIP5 simulations: Uncertain outcome, but consistent mechanisms, Global Biogeochem. Cy., 27, 1-15, doi:10.1002/gbc.20055, 2013.

Vetrov, A. A. and Romankevich, E. A.: Primary production and fluxes of organic carbon to the seabed in the Eurasian Arctic seas, 2003-2012, Dokl. Earth Sci., 454, 44-46, doi:10.1134/S1028334X14010073, 2014.

Wang, M. and Overland, J. E.: A sea ice free summer Arctic within 30 years: An update from CMIP5 models, Geophys. Res. Lett., 39, L18501, doi:10.1029/2012GL052868, 2012.

Wassmann, P. and Reigstad, M.: Future Arctic Ocean seasonal ice zones and implications for pelagic-benthic coupling, Oceanography, 24, 220-231, 2011.

Werner, I., Ikävalko, J., and Schünemann, H.: Sea-ice algae in Arctic pack ice during late winter, Polar Biol., 30, 1493-1504, doi:10.1007/s00300-007-0310-2, 2007.

Wheeler, P. A., Gosselin, M., Sherr, E., Thibault, D., Kirchman, D. L., Benner, R., and Whitledge, T. E.: Active cycling or organic carbon in the central Arctic Ocean, Nature, 380, 697-699, doi:10.1038/380697a0, 1996.

Wheeler, P. A., Watkins, J. M., and Hansing, R. L.: Nutrients, organic carbon and organic nitrogen in the upper water column of the Arctic Ocean: implications for the sources of dissolved organic carbon, Deep-Sea Res. Pt. II, 44, 1571-1592, 1997.

Yager, P. L., Connelly, T. L., Mortazavi, B., Wommack, K. E., Bauer, J. E., Opsahl, S., and Hollibaugh, J. T.: Dynamic bacterial and viral response to an algal bloom at subzero temperatures, Limnol. Oceanogr., 46, 790-801, 2011.

Yool, A., Martin, A. P., Fernández, C., and Clark, D. R.: The significance of nitrification for oceanic new production, Nature, 447, 999-1002, doi:10.1038/nature05885, 2007.

Zhang, J., Ashjian, C., Campbell, R., Hill, V., Spitz, Y. H., and Steele, M.: The great 2012 Arctic Ocean summer cyclone enhanced biological productivity on the shelves, J. Geophys. Res.Oceans, 119, 297-312, doi:10.1002/2013JC009301, 2014. 